Maurer School of Law: Indiana University

Digital Repository@ Maurer Law

Indiana Law Journal

Volume 96 | Issue 2

Article 1

Winter 2021

\title{
Consumer Perceptions of the Right to Repair
}

Aaron Perzanowski

Case Western Reserve University, akp73@case.edu

Follow this and additional works at: https://www.repository.law.indiana.edu/ilj

Part of the Environmental Law Commons, Law and Economics Commons, Law and Society

Commons, and the Legislation Commons

\section{Recommended Citation}

Perzanowski, Aaron (2021) "Consumer Perceptions of the Right to Repair," Indiana Law Journal: Vol. 96 : Iss. 2 , Article 1.

Available at: https://www.repository.law.indiana.edu/ilj/vol96/iss2/1

This Article is brought to you for free and open access by the Law School Journals at Digital Repository @ Maurer Law. It has been accepted for inclusion in Indiana Law Journal by an authorized editor of Digital Repository @ Maurer Law. For more information, please contact rvaughan@indiana.edu.

\section{$\Psi$}

JEROME HALL LAW LIBRARY

INDIANA UNIVERSITY

Maurer School of Law
Bloomington 


\title{
Consumer Perceptions of the Right to Repair
}

\author{
AARON PERZANOWSKI*
}

Device makers from Apple to John Deere have adopted designs and embraced strategies that thwart the repair of the products they sell. In response, state legislatures across the country are considering bills that would require firms to share replacement parts, tools, software updates, and documentation with independent repair shops and consumers. Beyond those legislative proposals, the battle over repair extends to courts, administrative agencies, and even presidential campaigns. As a matter of both policy and legal doctrine, that debate must be informed by consumer attitudes and expectations. Do consumers prefer the convenience and simplicity of replacing their devices when something goes wrong? Or do they expect and value the ability to repair the things they own? If repair restrictions interfere with such expectations and prevent consumers from engaging in lawful repairs, the case for intervention is more persuasive. This Article presents the results of a nationwide survey of consumers of electronic devices and explores its implications for the burgeoning right to repair movement.

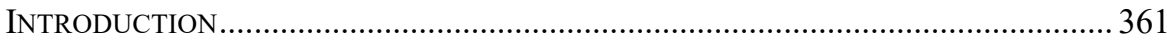

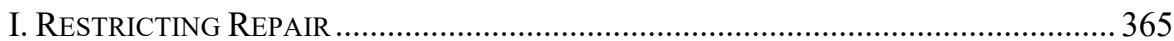

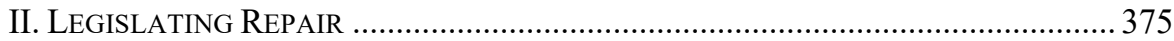

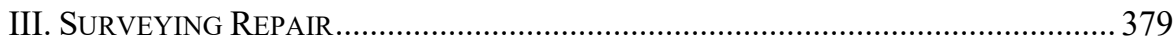

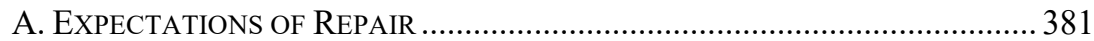

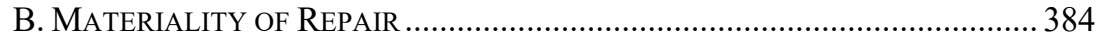

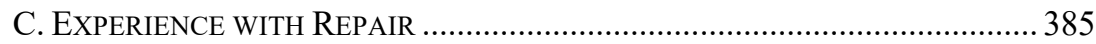

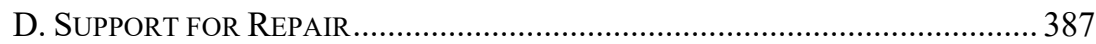

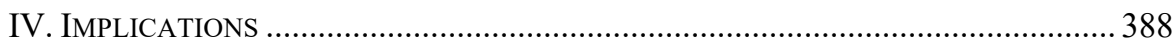

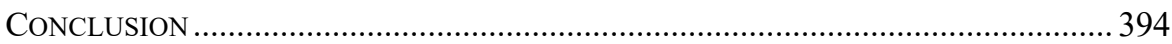

\section{INTRODUCTION}

Every year, fifty million people in the United States break their smartphone screens. ${ }^{1}$ Those who can afford it face a choice - either repair or replace their phones. A new screen for an iPhone $\mathrm{X}$ costs as little as $\$ 30$ from a third-party seller. ${ }^{2}$ But replacing the screen requires tools, skills, and confidence many consumers lack. In comparison, Apple currently charges \$279 for this fairly straightforward repair, a fee

* Professor of Law, Oliver C. Schroeder Jr. Distinguished Research Scholar, Case Western Reserve University. My thanks to Alissa Centivany, Leah Chan Grinvald, Chris Jay Hoofnagle, Jake Linford, Nathan Proctor, and Kyle Wiens for their comments.

1. Jared Gilmour, Americans Break Two Smartphone Screens Each Second, Costing \$3.4 Billion a Year, Report Says, Miami Herald (Nov. 21, 2018, 5:51 PM), https://www.miamiherald.com/news/nation-world/national/article222040170.html [https://perma.cc/9MQK-6BCJ].

2. See, e.g., iPhone X Glass Screen Replacement Premium Repair Kit, Phone Remedies, https://phoneremedies.com/products/iphone-X-glass-screen-replacement-premium-repair-kitblack-or-white [https://perma.cc/CMV5-QYUQ] (listing price of \$29.99). 
that often makes purchasing a new phone more attractive. ${ }^{3}$ And Apple further entices customers by offering discounts on new phones if they trade in their existing device instead of fixing it. ${ }^{4}$

Apple's apparent preference for replacement over repair is economically rational. At the time of its release, the iPhone $X$ cost Apple about $\$ 350$ to make, but it sold for $\$ 999 .^{5}$ That's a profit margin of $64 \%{ }^{6}$ The company sold 218 million phones in 2018 alone, generating over $\$ 140$ billion. ${ }^{7}$ In contrast, Apple claims that it makes no profit at all on repair services. ${ }^{8}$ The company even blamed the popularity of its own battery replacement program for declining iPhone sales. ${ }^{9}$

But the problem does not begin and end with iPhones. While Apple may be the most visible repeat offender, car owners, ${ }^{10}$ farmers, ${ }^{11}$ photographers, ${ }^{12}$ and even

3. iPhone Screen Repair, APPLE, https://support.apple.com/iphone/repair/service/screen -replacement [https://perma.cc/5G5U-WTEL] (listing prices between \$279 and \$329 to repair an iPhone X, depending on the specific model). For experienced repair providers, screen replacement is routine. But the task is manageable even for a novice. According to iFixit's step-by-step guide, it is a moderate repair that takes about an hour. See Jeff Suovanen, iPhone $X$ Screen Replacement, IFIXIT, https://www.ifixit.com/Guide/iPhone+X+Screen+Replacement /102423 [https://perma.cc/XSM4-P548].

4. Apple Trade In, APPLE, https://www.apple.com/shop/trade-in [https://perma.cc /H7WG-SVNC] (offering incentives up to $\$ 500$ for trading in a used phone). Apple does not disclose the percentage of trade-ins that are recycled as opposed to those that are refurbished for resale.

5. Stephen Nellis, Apple's iPhone $X$ has Higher Margin than iPhone 8: Analysis, REUTERS, (Nov. 6, 2017, 4:39 PM), https://www.reuters.com/article/us-apple-iphone/applesiphone-x-has-higher-margin-than-iphone-8-analysis-idUSKBN1D62RZ [https://perma.cc 15YSM-S3VA].

6. $I d$.

7. Tripp Mickle, Apple Reports Record Results but Weak Revenue Outlook, WaLL StREET J. (Nov. 1, 2018, 4:47 PM), https://www.wsj.com/articles/apple-reports-recordrevenue-and-profit-1541104284 [https://perma.cc/REE7-3VJC]; Apple's iPhone Revenue from 3rd Quarter 2007 to 4th Quarter 2019, STATISTA, https://www.statista.com/statistics /263402/apples-iphone-revenue-since-3rd-quarter-2007 [https://perma.cc/3UJJ-YWTW]; Global Apple iPhone Sales from 3rd Quarter 2007 to 4th Quarter 2018, STATISTA, https://www.statista.com/statistics/263401/global-apple-iphone-sales-since-3rd-quarter-2007 [https://perma.cc/L3JY-BR34].

8. Lauren Goode, Right-to-Repair Groups Don't Buy Apple's Answers to Congress, WIRED (Nov. 27, 2019, 11:01 AM), https://www.wired.com/story/right-to-repair-appleanswers-congress [https://perma.cc/7FNH-MBVG].

9. Jason Koebler, Tim Cook to Investors: People Bought Fewer New iPhones Because They Repaired Their Old Ones, VICE (Jan. 2, 2019, 5:56 PM), https://www.vice.com/en_us /article/zmd9a5/tim-cook-to-investors-people-bought-fewer-new-iphones-because-theyrepaired-their-old-ones [https://perma.cc/4QAB-MB4C].

10. See Leah Chan Grinvald \& Ofer Tur-Sinai, Smart Cars, Telematics and Repair, U. Mich. J.L. REFORM (forthcoming 2020).

11. Jason Koebler, Why American Farmers Are Hacking Their Tractors with Ukrainian Firmware, VICE (Mar. 21, 2017, 4:17 PM), https://www.vice.com/en_us/article/xykkkd/whyamerican-farmers-are-hacking-their-tractors-with-ukrainian-firmware [https://perma.cc /X5K8-QUBZ].

12. Steve Dent, Nikon Ends its Authorized Third-Party Repair Program, Engadget, 
hospitals ${ }^{13}$ are forced to contend with repair restrictions. Device makers rely on an assortment of economic, technological, and legal techniques to curtail repair. Repair services are priced to encourage replacement. Marketing strategies emphasize incremental feature improvement to drive short upgrade cycles. Product designs incorporate components that are difficult to replace or require expensive tools. Some devices, for all practical purposes, are impossible to repair. ${ }^{14}$ And as products increasingly depend on local or cloud-based software code for their basic functionality, device makers have even greater power to restrict repair. Firms also rely on legal threats, ranging from voided warranties to copyright and patent claims, to chill repair.

Taken together, these strategies allow firms to extract an increasing share of consumer surplus. But even putting aside the impact on consumers' pocketbooks, the decision to replace rather than repair has far-reaching consequences. About 1.5 billion mobile phones are sold annually worldwide, ${ }^{15}$ contributing to the more than fifty million tons of electronic waste produced every year. ${ }^{16}$ Electronics currently account for $70 \%$ of the toxic waste in U.S. landfills, a figure that continues to rise. ${ }^{17}$ That e-waste includes lithium, mercury, and lead - chemicals that endanger our water supplies and threaten human health. ${ }^{18}$

Even before the end of the product lifecycle, manufacturing and global shipping produce significant pollution. ${ }^{19}$ And extracting the raw materials needed to produce

(Dec. 10, 2019), https://www.engadget.com/2019-12-10-nikon-ends-authorized-third-partyrepairs.html [https://perma.cc/BJ86-Y8CG].

13. Jason Koebler, Hospitals Need to Repair Ventilators. Manufacturers Are Making That Impossible, VICE (Mar. 18, 2020, 2:15 PM), https://www.vice.com/amp/en_us/article /wxekgx/hospitals-need-to-repair-ventilators-manufacturers-are-making-that-impossible [https://perma.cc/C2PF-2WT9].

14. See AirPods Teardown, IFIXIT (Dec. 20, 2016), https://www.ifixit.com/Teardown /AirPods+Teardown/75578 [https://perma.cc/Q695-KNUM] (giving the AirPods a repairability score of zero); AirPods Pro Teardown, IFIXIT (Oct. 31, 2019), https://www.ifixit.com/Teardown/AirPods+Pro+Teardown/127551 [https://perma.cc/86HG -BB6N] (giving the AirPods Pro a repairability score of zero).

15. How to Recycle Old Electronics, CONSUMER RePS. (Apr. 22, 2018), https://www.consumerreports.org/recycling/how-to-recycle-electronics [https://perma.cc /FC7S-LPB5] (noting sales of 1.5 billion in 2017); Andy Boxall, In 2018, Smartphone Sales Stopped Growing Annually for the First Time, Digit. TRENDS (Jan. 31, 2019), https://www .digitaltrends.com/mobile/2018-smartphone-sales-decline-news [https://perma.cc/532M -RLJV] (noting 1.43 billion sales in 2018, down from 1.51 billion in 2017).

16. UN Report: Time to Seize Opportunity, Tackle Challenge of E-Waste, U.N. ENV'T Programme (Jan. 24, 2019), https://www.unenvironment.org/news-and-stories/press-release /un-report-time-seize-opportunity-tackle-challenge-e-waste [https:/perma.cc/SZS9-ABMZ].

17. Peter Holgate, The Model for Recycling Our Old Smartphones is Actually Causing Massive Pollution, Vox (Nov. 8, 2017, 12:30 PM), https://www.vox.com/2017/11/8 /16621512/where-does-my-smartphone-iphone-8-x-go-recycling-afterlife-toxic-wasteenvironment [https://perma.cc/FD4R-G8LJ].

18. Aleksandra Wisniewska, What Happens to Your Old Laptop? The Growing Problem of E-waste, Fin. TiMES (Jan. 10, 2020), https://www.ft.com/content/26e1 aa74-2261-11ea-92da -f0c92e957a96 [https://perma.cc/856X-PD9J].

19. Maddie Stone, Could Letting Consumers Fix their iPhones Help Save the Planet?, GRIST, (Nov. 11, 2019), https://grist.org/article/could-letting-consumers-fix-their-own 
our devices inflicts both environmental and human costs. Cobalt, for example, is a crucial component in the lithium-ion batteries found in phones, laptops, and electric vehicles..$^{20}$ Global demand for cobalt exceeds 100,000 tons per year. ${ }^{21}$ That number is expected to increase threefold over the next decade. ${ }^{22}$ Most of the world's cobalt supply is found in the Democratic Republic of Congo. ${ }^{23}$ Roughly $20 \%$ of it is mined by hand by a quarter million local creuseurs. They work in narrow, unstable tunnels, inhaling toxic cobalt dust, for less than a dollar a day. ${ }^{24}$ And an estimated 35,000 of them are children as young as six years old.$^{25}$ By encouraging us to replace rather than repair our devices, manufacturers are increasing the already high demand for materials like cobalt. In the process, they are amplifying the negative environmental and human rights externalities created by global electronics production.

The COVID-19 pandemic has dramatically highlighted the immediate consequences of repair on human welfare. As hospitals across the globe faced shortages of life-saving ventilators, and manufacturers scrambled to ramp up production, the ability to maintain and repair existing equipment emerged as a pressing problem. Authorized repair, which often requires shipping devices back to the manufacturer, can leave hospitals without critical equipment for days or weeks. ${ }^{26}$ In other instances, manufacturers failed to supply replacement parts, imperiling patients. When a hospital in Chiari, Italy, couldn't secure valves for its respirators from the manufacturer, local volunteers designed and 3D-printed 100 replacements that cost no more than a few dollars apiece. ${ }^{27}$ The volunteers managed this feat in just two days, ${ }^{28}$ with no help from the manufacturer, which refused to share design specifications. ${ }^{29}$

Motivated by these social, economic, and environmental justice imperatives, a collection of repair providers, policy advocates, tinkerers, and everyday consumers

-iphones-help-save-the-planet [https://perma.cc/HE9F-NKU7].

20. Siddharth Kara, Is Your Phone Tainted by the Misery of the 35,000 Children in Congo's Mines?, GuARDIAN (Oct. 12, 2018, 4:00 AM), https://www.theguardian.com/global -development/2018/oct/12/phone-misery-children-congo-cobalt-mines-drc [https://perma.cc /CQ2N-Y9TA].

21. Sarah Katz-Lavigne, Demand for Congo's Cobalt is on the Rise. So is the Scrutiny of Mining Practices, WASH. Post (Feb. 21, 2019, 7:00 AM), https://www.washingtonpost.com /politics/2019/02/21/demand-congos-cobalt-is-rise-so-is-scrutiny-mining-practices [https://perma.cc/H4DD-ZWWL].

22. See Cobalt: Demand-Supply Balances in the Transition to Electric Mobility, at 62 63, EUR 29381 EN, Joint Research Center (2018).

23. Kara, supra note 20.

24. Id.

25. Id.

26. Koebler, supra note 13.

27. Amy Feldman, Meet the Italian Engineers 3D-Printing Respirator Parts for Free to Help Keep Coronavirus Patients Alive, Forbes (Mar. 19, 2020, 3:57 PM), https:/www.forbes.com/sites/amyfeldman/2020/03/19/talking-with-the-italian-engineerswho-3d-printed-respirator-parts-for-hospitals-with-coronavirus-patients-for-free /\#30be5fdf78f1 [https://perma.cc/TW8X-DVVC].

28. Id.

29. Jay Peters, Volunteers Produce 3D-Printed Valves for Life-Saving Coronavirus Treatments, Verge (Mar. 17, 2020, 6:51 PM), https:/www.theverge.com/2020/3/17 
has coalesced. This right to repair movement has pressured state and federal authorities to recognize the existing barriers to repair and to adopt legal interpretations, regulations, and statutes that would empower consumers to repair the things they own. Despite widespread public support, the efforts of the right to repair movement have faced effective resistance through the lobbying efforts of device makers like Apple and John Deere. ${ }^{30}$ But the fight over repair remains an active one. In 2019, right to repair bills were introduced in twenty statehouses around the country. ${ }^{31}$ And 2020 promises similar levels of activity.

Part I of this Article details the strategies upon which device makers rely to frustrate repair. Part II considers legislative interventions intended to push back on existing barriers to repair, with a particular focus on the set of bills introduced in state legislatures across the United States. Part III describes the results of a survey of more than 800 U.S. consumers, focusing on their expectations of and experiences with the repair of electronic devices. The legal and policy implications of those results are discussed in Part IV.

\section{RESTRICTING REPAIR}

Restrictions on repair take a number of forms. Some are decades old. Others, enabled by changes in technology and law, are more recent innovations. Some are deliberate efforts to thwart repair. Others reflect indifference to reparability or a failure to prioritize it. In practice, it can be difficult to disentangle the motivations underlying product design, pricing, and other decisions that negatively affect repair. Design choices that affect repair can sometimes be justified in terms of aesthetics, usability, performance, and consumer safety. But less benevolent motivations are sometimes apparent. ${ }^{32}$ Regardless of intent, the techniques described below enable firms to exert considerable power over consumers' ability to repair their devices.

In large measure, the ease with which a device can be repaired is a function of its physical design. A firm determined to limit repair has no shortage of options. Rather than standard screws, they can opt for new variants, like Pentalobe screws. ${ }^{33}$

/21184308/coronavirus-italy-medical-3d-print-valves-treatments [https://perma.cc/96QM -CCHP].

30. Jason Koebler, Apple Is Lobbying Against Your Right to Repair iPhones, New York State Records Confirm, VICE (May 18, 2017, 8:00 AM), https://www.vice.com/en_us/article /nz85y7/apple-is-lobbying-against-your-right-to-repair-iphones-new-york-state-records -confirm [https://perma.cc/RB8W-J2JE]; Matthew Gault, Maryland Suddenly Looks Like It Might Break John Deere's Repair Monopoly, VICE (Mar. 12 2020, 8:38 AM), https://www.vice.com/en_us/article/k7ekzw/maryland-suddenly-looks-like-it-might-breakjohn-deeres-repair-monopoly [https://perma.cc/4FYC-R4FN].

31. Nathan Proctor, Right to Repair Wraps Up a Big Year, U.S. PIRG (Dec. 26, 2019), https://uspirg.org/blogs/blog/usp/right-repair-wraps-big-year[https://perma.cc/RZF5-JQQW].

32. See Koebler, supra note 9; Rajesh Kumar Singh, Deere Bets on Cost Cuts, Services Push to Boost Profits, Reuters (Jan. 8, 2020, 3:55 PM), https://www.reuters.com/article/usdeere-strategy/deere-bets-on-cost-cuts-services-push-to-boost-profits-idUSKBN1Z72TA [https://perma.cc/Z4SF-MRX7] (noting that John Deere is "betting on its parts and maintenance services business" to increase profits).

33. Kyle Wiens, Apple's Diabolical Plan to Screw Your iPhone, IFIXIT (Jan. 20, 2011), https://www.ifixit.com/News/14279/apples-diabolical-plan-to-screw-your-iphone 
Specialized screws - and more importantly, the associated screwdrivers-are typically less common and more expensive. Even worse, device makers can simply glue components together rather than use screws or other fasteners. Glue often makes it difficult to replace a single component without removing or damaging others. ${ }^{34}$ Some components, like batteries, are naturally less durable and more prone to failure than others. ${ }^{35}$ When firms design their products in ways that complicate the procedure for replacing these predictable points of failure, they increase the cost of repair.

As a matter of product design, Apple's AirPod wireless headphones embody a ruthless hostility to repair. They retail for $\$ 159$ for the basic version and $\$ 249$ for the Pro model.$^{36}$ Apple sold thirty-five million pairs in $2018,{ }^{37}$ and nearly sixty million in 2019. ${ }^{38}$ Despite their price tag, AirPods fail to live up to their advertised five-hour playback time after as little as eighteen months. ${ }^{39}$ Owners report batteries that last for only fifteen to thirty minutes on a full charge. ${ }^{40}$ Unlike flashlights and remote controls, and even some laptops and smartphones, AirPod batteries cannot be easily replaced. AirPods have no screws; they are held together by glue and solder. ${ }^{41}$ Accessing the battery requires a special vibrating knife to cut through the plastic shell. ${ }^{42}$ The procedure is all the more harrowing since the battery, about the thickness of a spaghetti noodle, is prone to combustion if punctured.$^{43}$ But even assuming you can dislodge it safely, your AirPods will be irretrievably damaged in the process.

Beyond physical design, the widespread adoption of digital technologies has enabled a new set of more sophisticated restraints on repair. The functionality of devices from toasters to cars is controlled by embedded software code. That code, in turn, gives device makers even greater leverage over post-sale consumer behavior, including repair. Apple's Error 53 scandal is a useful illustration. In 2016, iPhone owners whose devices had been serviced by independent repair shops were shocked when their devices would not start up, and their contacts, photos, and other data were

[https://perma.cc/N2SJ-494G].

34. See Geoffrey A. Fowler, Everyone's AirPods Will Die. We've Got the Trick to Replacing Them, WASH. Post (Oct. 8, 2019, 11:00 AM), https://www.washingtonpost.com /technology/2019/10/08/everyones-airpods-will-die-weve-got-trick-replacing-them [https://perma.cc/Z4XC-LKU7].

35. See id.

36. Shop AirPods, APPLE, https://www.apple.com/shop/select-airpods [https://perma.cc /WF7Z-ZYW9].

37. Jeremy White, The Secrets Behind the Runaway Success of Apple's AirPods, WIRED (May 9, 2020), https://www.wired.co.uk/article/apple-airpods-success [https://perma.cc /WHN4-MX5T].

38. Charlie Wood, Apple Sold Nearly 60 Million AirPods in 2019, Analysts Estimate, Bus. INSIDER (Jan. 16, 2020, 7:45 AM), https:/www.businessinsider.com/apple-sold-nearly-60 -million-airpods-in-2019-strategy-analytics-2020-1 [https://perma.cc/CY4S-JC2P].

39. Alana Semuels, Your AirPods Will Die Soon, ATL. (Mar. 21, 2019), https:/www.theatlantic.com/technology/archive/2019/03/your-airpods-probably-have -terrible-battery-life/585439 [https://perma.cc/LFH3-CY22]; Fowler, supra note 34.

40. See Fowler, supra note 34.

41. Semuels, supra note 39.

42. Fowler, supra note 34.

43. Id. 
inaccessible. ${ }^{44}$ Phones that were working normally for weeks or months were suddenly "bricked" after the installation of an Apple software update. ${ }^{45}$ That new code was designed to detect a replacement connector between the device's home button and its Touch ID sensor, a reliable indicator of third-party repair. ${ }^{46}$ And when the connector was found, the software instructed the phone to stop working altogether. ${ }^{47}$

Firms have relied on a variety of planned obsolescence strategies to shorten the life of their products for nearly a century. ${ }^{48}$ Today, they can leverage software to artificially degrade product performance and spur consumers to buy replacements. Apple recently agreed to pay $\$ 500$ million to settle a series of class action lawsuits over its throttling of older iPhones. ${ }^{49}$ In 2017, Reddit users uncovered Apple's practice of intentionally slowing down the processors of iPhones with weak batteries. ${ }^{50}$ Apple later admitted that code in its iOS software detected aging batteries and reduced the device's processor speed. ${ }^{51}$ According to Apple, this move was intended to prevent unexpected shutdowns. ${ }^{52}$ But since this code was not disclosed to consumers, the cause of their device's slow performance remained a mystery. Many bought new devices rather than simply replace their phone's battery. ${ }^{53}$ Apple's throttling and the secrecy surrounding it steered consumers away from repair and toward replacement, inflating Apple's bottom line in the process.

The proliferation of so-called "smart" products also undermines repair by removing functionality from local devices and outsourcing it to remote servers. ${ }^{54} \mathrm{Jibo}$ was a foot-tall plastic robot with an emotive face and sensors that responded to

44. Matthew Panzarino, Apple Apologizes and Updates iOS to Restore iPhones Disabled by Error 53, TeCHCRUNCH (Feb. 18, 2016, 1:01 PM), https://techcrunch.com/2016/02/18 /apple-apologizes-and-updates-ios-to-restore-iphones-disabled-by-error-53 [https://perma.cc /SKP2-N7Z9]; Miles Brignall, 'Error 53' Fury Mounts as Apple Software Update Threatens to Kill Your iPhone 6, GUARDIAN (Feb. 5, 2016, 1:59 PM), https://www.theguardian.com /money/2016/feb/05/error-53-apple-iphone-software-update-handset-worthless-third-partyrepair [https://perma.cc/82F6-EQRB].

45. Brignall, supra note 44.

46. Panzarino, supra note 44.

47. Id.

48. See generally VAnCe PACKARd, The WASTE Makers (1960) (detailing the emergence of planned obsolescence in the early twentieth century).

49. Adi Robertson, Apple Agrees to $\$ 500$ Million Settlement for Throttling Older iPhones, VERGE (Mar. 2, 2020, 12:01 PM), https://www.theverge.com/2020/3/2/21161271/apple -settlement-500-million-throttling-batterygate-class-action-lawsuit [https://perma.cc/CKJ3 $-\mathrm{J} 9 \mathrm{EU}]$.

50. Tom Warren \& Nick Statt, Apple Confirms iPhones with Older Batteries Will Take Hits in Performance, VERGE (Dec. 20, 2017, 2:47 PM), https://www.theverge.com/2017/12/20 /16800058/apple-iphone-slow-fix-battery-life-capacity [https://perma.cc/ZE73-X6PY].

51. $I d$.

52. Id.

53. Robertson, supra note 49.

54. This shift also amplifies concerns around privacy and security, among other things. See Chris Jay Hoofnagle, Aniket Kesari \& Aaron Perzanowski, The Tethered Economy, 87 Geo. WASH. L. ReV. 783 (2019). 
physical interaction that sold for $\$ 900 .^{55}$ It could dance, talk, and play games with its owners. When the company that built Jibo failed, it powered down its servers. ${ }^{56}$ Since most of Jibo's functionality depended on those distant servers rather than the device's on board computer, Jibo suffered from "digital dementia." The robot went limp, its dimly lit screen blank. And its head and torso "twist[ed] freely, like a lifeless body." 57 Although Jibo's physical components could be repaired, most of its features were housed on a remote server that Jibo owners could not access, let alone repair. ${ }^{58}$

In addition to product design, device makers leverage economic tools to dissuade repair. When consumers are deciding whether to repair a device or replace it, they are understandably sensitive to the cost differential between those two options. ${ }^{59}$ The smaller the difference, the more likely they are to opt for a new device. One way to narrow that gap is by charging high prices for repair. Samsung, for example, charges as much as $\$ 279$ to replace the screen on its Galaxy phones and up to $\$ 599$ for foldable screens. ${ }^{60}$ Likewise, firms like John Deere see repair services as a growth sector, one from which they can extract significant profits. ${ }^{61}$

Trade-in programs are another economic tool device makers deploy to discourage repair. Those incentives reduce the cost advantage of repair even further by offering consumers discounts on new devices in exchange for discarding their old ones. As Apple encourages its customers, "Turn the device you have into the one you want." 62 Not only do these programs entice consumers to buy new devices at incredibly high markups, but they also help firms control secondary markets for used devices. In some instances, trade-ins are refurbished and resold by the manufacturer. In other cases, trade-ins are recycled - that is, harvested for raw materials used to produce new, more expensive devices. ${ }^{63}$ But in either case, trade-in programs help firms like

55. Jeffrey Van Camp, My Jibo Is Dying and It's Breaking My Heart, Wired (Mar. 8, 2019, 9:00 AM), https://www.wired.com/story/jibo-is-dying-eulogy [https://perma.cc/S46J -XSRU].

56. $I d$.

57. $I d$.

58. See id.

59. Cf. Sangman Han, Sunil Gupta \& Donald R. Lehmann, Consumer Price Sensitivity and Price Thresholds, 77 J. RetaiLING 435, 435-6 (2001) ("Price has a significant influence on consumers' purchase behavior and consequently on firm sales and profits.").

60. Samsung-Authorized Galaxy Repair Services, SAMSUNG, https://www.samsung.com /us/support/repair/pricing/ [https://perma.cc/F652-H2UY].

61. Singh, supra note 32 .

62. Apple Trade In, supra note 4.

63. Electronics recycling is itself problematic. In many instances, devices are shredded and the metal components are shipped to polluting smelters. Other times, devices are shipped to scrapyards in developing economies. Holgate, supra note 17. To their credit, companies like Apple have invested in improving this process. But they still recycle only a tiny fraction of the devices distributed into the global ecosystem. Apple's Daisy robot, for example, can recycle only 1.2 million iPhones per year. Dani Deahl, Daisy Is Apple's New iPhone-Recycling Robot, VerGE (Apr. 19, 2018, 2:17 PM), https://www.theverge.com/2018/4/19/17258180 /apple-daisy-iphone-recycling-robot [https://perma.cc/RYG2-4DVX]; Press Release, Apple, Apple Expands Global Recycling Programs (Apr. 18, 2019), https://www.apple.com /newsroom/2019/04/apple-expands-global-recycling-programs [https:/perma.cc/VYR9 -PH3F]. 
Apple prevent goods from entering the broader used marketplace where they can drive down the demand for-and price of - new devices. Of course, firms can also simply refuse to repair products at all. Apple, for example, distinguishes between "vintage" products - those that haven't been manufactured in the last five yearsand "obsolete" products - those that haven't been manufactured in the last seven years. ${ }^{64}$ For vintage products, Apple makes no guarantees that repair is available, unless mandated by law. ${ }^{65}$ For obsolete products, "Apple has discontinued all hardware service . . . with no exceptions." ${ }^{\prime 66}$ Nor will Apple sell parts to service providers for such products. ${ }^{67}$

But alone, a device maker's internal policies and pricing for repair are ineffective so long as a competitive market for third-party repair thrives. If Samsung charges $\$ 279$ to repair a cracked screen, but a reliable independent repair shop will do the job for $\$ 100$, consumers conscious of price or environmental impact will simply patronize a locally owned repair shop. And for consumers confident in their own mechanical skills, or simply willing to learn, they can attempt self-repair for the cost of tools and parts. In order to stamp out the market for repairs - or capture its valuefirms must either eliminate third-party and self-repair altogether or increase their costs to the point of unviability.

Device makers adopt a variety of strategies to make life difficult for independent repair shops and consumers. Aside from design choices that frustrate repair, device makers have attempted to limit the availability of materials and information crucial to the practice of repair. As discussed in more detail below, firms make it difficult to acquire replacement parts. The simplest measure is to refuse to sell parts to thirdparty repair providers, as camera-maker Nikon does. ${ }^{68}$ Firms also tightly control access to diagnostic tools necessary to identify malfunctions. ${ }^{69}$ And they lock down schematics and manuals that would facilitate repair. Dräger, a medical device manufacturer, prevented the distribution of repair manuals for ventilators, a decision that led to criticism during the COVID-19 pandemic. ${ }^{70}$ Even repair shops that are "authorized" by manufacturers are not immune. Nikon decided in late 2019 to end

64. Vintage and Obsolete Products, APPLE, https://support.apple.com/en-us/HT201624 [https://perma.cc/P84A-VLWY].

65. Id. This distinction is likely a response to California's Song-Beverly Consumer Warranty Act, which requires that "[e]very manufacturer making an express warranty with respect to an electronic or appliance product ... with a wholesale price to the retailer of one hundred dollars $(\$ 100)$ or more, shall make available to service and repair facilities sufficient service literature and functional parts to effect the repair of a product for at least seven years after the date a product model or type was manufactured." CAL. CIV. CODE $§ 1793.03$ (b).

66. Vintage and Obsolete Products, supra note 64.

67. Id.

68. Elizabeth Chamberlain, How Nikon Is Killing Camera Repair, IFIXIT (Feb. 14, 2012), https://www.ifixit.com/News/1349/how-nikon-is-killing-camera-repair [https://perma.cc /BNW4-2QY4].

69. Koebler, supra note 11.

70. Koebler, supra note 13. 
its support for fifteen authorized repair shops, leaving its customers with just two locations in the United States to have their cameras repaired. ${ }^{71}$

Software gives device makers another mechanism for increasing the costs of independent repair. For example, the software embedded in John Deere tractorswhich cost farmers as much as $\$ 800,000$ each $^{72}$ - requires authentication of new parts before the vehicle will recognize them. ${ }^{73}$ So, a farmer who buys something as simple as a turn signal and installs it herself or pays an independent repair shop to install it is still forced to pay the local John Deere dealer to send a technician to authenticate the part before it will work, for a fee of $\$ 230$, plus $\$ 130$ an hour for the technician. ${ }^{74}$

Undergirding many of these strategies are legal regimes that offer device makers considerable power over post-sale use of their products. ${ }^{75}$ Copyright, patent, trademark, trade secret, and contract law are all tools firms can leverage to threaten consumers and independent repair providers with potentially ruinous liability and legal fees. To be clear, these threats are highly contestable. But regardless of their ultimate merits, they have a chilling effect on repair. Given the uncertainty of litigation, the expense of mounting a robust defense, and massive resource disparities, consumers and repair providers are unlikely to withstand a lawsuit. ${ }^{76}$

One of the key legal tools firms have relied on to restrict repair is $\S 1201$ of the Digital Millennium Copyright Act (DMCA). ${ }^{77}$ That statute makes it unlawful to circumvent - that is, to remove, bypass, or disable-technological protection measures (TPMs) that restrict access to copyrighted works. ${ }^{78}$ In addition, $\S 1201$ 's antitrafficking provisions prohibit the creation, sale, or distribution of tools that enable circumvention. ${ }^{79}$ Device makers routinely use TPMs to limit access to the software code that controls devices from smartphones to cars. That code is often

71. Kevin Purdy, Nikon Is Killing Its Authorized Repair Program, IFIXIT (Dec. 9, 2019), https://www.ifixit.com/News/34241/nikon-is-killing-its-authorized-repair-program [https://perma.cc/4BDX-CS3C].

72. Peter Waldman \& Lydia Mulvany, Farmers Fight John Deere over Who Gets to Fix an \$800,000 Tractor, BLOOMBERG (Mar. 5, 2020, 5:00 AM), https://www.bloomberg.com /news/features/2020-03-05/farmers-fight-john-deere-over-who-gets-to-fix-an-800-000tractor [https://perma.cc/Q8ZW-FQRS]

73. Koebler, supra note 11.

74. Id.

75. For a thorough discussion of the intellectual property issues in the repair context, see Leah Chan Grinvald \& Ofer Tur-Sinai, Intellectual Property Law and the Right to Repair, 88 FordHAM L. REV. 63 (2019).

76. See Jessica Bursztynsky, Apple Now Has $\$ 192.8$ Billion in Cash on Hand, Down from Last Quarter, CNBC (Apr. 30, 2020, 4:41 PM), https://www.cnbc.com/2020/04/30/apple-q2 -2020-cash-hoard-heres-how-much-apple-has-on-hand.html [https://perma.cc/S6SJ-UF53]; see generally Anne Sraders, Markets Rally for a Second Day, Pushing Apple's Market Cap Back Above \$1 Trillion, ForBes (Mar. 25, 2020, 4:21 PM), https://fortune.com/2020/03/25 /aapl-apple-stock-market-cap-dow-jones-sp-500-today-news-rally [https://perma.cc/2MVU -9LWK] (illustrating the enormity of resources at Apple's disposal because of the company's size and power).

77. 17 U.S.C. $\S 1201$.

78. Id. $\S 1201(\mathrm{a})$.

79. Id. $\S 1201(\mathrm{~b})$. 
necessary to diagnose and repair devices. These digital locks pose practical hurdles for repair. But $\S 1201$ compounds those difficulties by introducing potential legal liability for repairers who remove or bypass such digital locks. ${ }^{80}$

To some extent, that risk has been mitigated by exemptions from circumvention liability recommended by the Copyright Office and adopted by the Librarian of Congress in the triennial DMCA rulemaking. ${ }^{81}$ In 2015, the Librarian adopted an exemption permitting the circumvention of measures applied to "[c]omputer programs that are contained in and control the functioning of a motorized land vehicle . . . when circumvention is a necessary step undertaken by the authorized owner of the vehicle to allow the diagnosis, repair or lawful modification of a vehicle function." 82 In the next rulemaking, that exemption was renewed and expanded to include "[c]omputer programs that are contained in and control the functioning of a lawfully acquired smartphone or home appliance or home system, such as a refrigerator, thermostat, HVAC or electrical system." 83

These exemptions, while an important success for repair advocates, are limited in important respects. First, they do not include devices like tablets, smart speakers, cameras, televisions, and game consoles. Second, they are temporary. In 2021, the Copyright Office will conduct another rulemaking and may revise, narrow, or eliminate these exemptions altogether. ${ }^{84}$ Third, exemptions are limited to $\S 1201$ 's anticircumvention provisions. They provide no defense to the prohibition on trafficking in circumvention tools. ${ }^{85}$ In other words, while it is lawful to circumvent in order to repair these devices, it remains unlawful to create or share tools that enable circumvention. This creates significant practical hurdles for consumer repair and increases the risks facing independent repair providers who may develop such tools in-house. Finally, the exemptions do not address various forms of liability beyond $\S 1201$.

The license John Deere distributes with its farm equipment illustrates some of those risks. As discussed above, John Deere uses proprietary software tools to authenticate and calibrate replacement parts ${ }^{86}$ In response, some farmers have turned

80. Violations of $\S 1201$ give rise to actual or statutory damages in a civil case, up to five years in prison, and a $\$ 500,000$ fine for a first offense. Id. $\S \S 1203-1204$.

81. See id. $\S 1201(\mathrm{a})(1)(\mathrm{C})$.

82. Exemption to Prohibition on Circumvention of Copyright Protection Systems for Access Control Technologies, 80 Fed. Reg. 65954, 65963 (Oct. 28, 2015).

83. Exemption to Prohibition on Circumvention of Copyright Protection Systems for Access Control Technologies, 83 Fed. Reg. 54010, 54030 (Oct. 26, 2018).

84. In 2018, the Office moved away from its prior practice of renewing each exemption proposal de novo and adopted a process of presumptive renewal in the absence of "meaningful opposition." U.S. Copyright Office, Streamlined Petitions for Renewed Exemptions (2018), https://www.copyright.gov/1201/1201_streamlined_renewal_transcript.pdf [https://perma.cc/27KF-QW84]. How long this new streamlined system will remain in effect is an open question.

85. 17 U.S.C. $\S 1201(a)$.

86. See supra text accompanying note 73. Apple relies on a similar strategy to discourage independent replacement of faulty batteries. Jason Koebler, Apple Is Locking Batteries to Specific iPhones, a Nightmare for DIY Repair, VICE (Aug. 8, 2019, 9:41 AM), https:/www.vice.com/en_us/article/59nz3k/apple-is-locking-batteries-to-specific-iphones-a -nightmare-for-diy-repair [https://perma.cc/K4BY-5AVY]. 
to Ukrainian websites that sell unauthorized copies of John Deere software as a means of bypassing these restrictions. ${ }^{87}$ Despite the $\S 1201$ exemption, those farmers likely face at least two sources of legal risk. First, paragraph 5(b) of the John Deere license says farmers promise not to "purchase . . . any circumvention or hacking device that is designed to circumvent or hack the [licensed software or product]." 88 By acquiring John Deere software from an unauthorized source, farmers have arguably violated this provision. Similarly, paragraph 4 states that farmers "may not transmit the [licensed software] over any network or via a hacking device." 89 That language suggests that using an unauthorized tool for diagnostic purposes would violate the license terms.

Aside from contract liability, farmers have to contend with copyright law. ${ }^{90}$ The act of downloading John Deere software without permission is a plausible act of infringement, despite the legality of any subsequent act of circumvention. Moreover, Deere would likely argue that once the terms of the license have been violated, simply using the equipment would constitute copyright infringement since embedded software is reproduced in the device's memory. ${ }^{91}$

But copyright isn't the only source of concern. Patent law, although generally accommodating of repair, gives manufacturers additional avenues for curtailing repair. Patent exhaustion dictates that after an authorized sale of a patented article, the patent holder cannot control the use or disposition of that particular article. ${ }^{92}$ As a result, owners of patented devices are free to repair them. ${ }^{93}$ But exhaustion does not apply to making or reproducing a patented device. ${ }^{94}$ Courts have therefore attempted to draw a line between repair and reconstruction. The former is lawful; the latter requires a license. But the line dividing those categories is sometimes ambiguous. ${ }^{95}$ That uncertainty can cast the shadow of potential liability over consumers and repair providers.

One strategy for frustrating repair is to obtain utility or design patents on components and replacement parts. Since device makers enjoy the exclusive right to make patented parts, they can starve repair providers of the replacement parts essential to their services. If repair providers try to manufacture parts themselves, they run the risk of patent infringement. For example, when Italian volunteers 3D

87. Koebler, supra note 11.

88. License Agreement for John Deere Embedded Software, JoHn DEERE, https://www.deere.com/privacy_and_data/docs/agreement_pdfs/english/2016-10-28

-Embedded-Software-EULA.pdf [https://perma.cc/Y8NX-HAJC].

89. Id.

90. See 17 U.S.C. § 504(c).

91. While plausible, this claim is dubious for at least two reasons. First, the RAM copy doctrine on which it is premised rests on dubious legal footing. See Aaron Perzanowski, Fixing RAM Copies, 104 Nw. U. L. Rev. 1067 (2010). Second, courts are reluctant to impose copyright liability for license violations that do not bear some reasonable connection to the underlying copyright interests. See MDY Indus., L.L.C. v. Blizzard Entm't., Inc., 629 F.3d 928, 941 (9th Cir. 2010).

92. See, e.g., Impression Prods., Inc. v. Lexmark Int'1, Inc., 137 S. Ct. 1523, 1526 (2017).

93. See Aro Mfg. Co. v. Convertible Top Replacement Co., 365 U.S. 336, 342-46 (1961).

94. Bowman v. Monsanto Co., 569 U.S. 278, 283-84 (2013).

95. See Mark D. Janis, A Tale of the Apocryphal Axe: Repair, Reconstruction, and the Implied License in Intellectual Property Law, 58 MD. L. REV. 423, 425 (1999). 
printed replacement ventilator valves in the midst of the COVID-19 pandemic, they were exposed to potential patent liability. ${ }^{96}$

Given that the standards the Patent Office and Federal Circuit apply to design patents, they provide an even more problematic opportunity to curtail the supply of replacement parts. ${ }^{97} \mathrm{~A}$ recent case decided by the Federal Circuit illustrates the worry. The Automotive Body Parts Association (ABPA) sued Ford, seeking a declaratory judgment invalidating two Ford design patents on a truck hood and head lamp. ${ }^{98}$ ABPA argued that since consumers prefer parts that not only serve the same function as the original but also "restore the original appearance of their vehicles," those designs should be deemed functional rather than merely ornamental. ${ }^{99}$ The Federal Circuit disagreed, holding that "the aesthetic appeal of a design to consumers is inadequate to render that design functional." 100 The court also rejected ABPA's exhaustion and repair arguments. Although the sale of a vehicle exhausts Ford's control over the physical components that make up that vehicle, that sale does not entitle the owner to use unauthorized parts that embody a patented design. ${ }^{101}$ And since Ford's design patents addressed specific components of the vehicle rather than the vehicle in its entirety, patent law's right of repair did not embrace the use of unauthorized copies of those components. ${ }^{102}$ The willingness of the Patent Office and the Federal Circuit to accept design patents directed to parts of products - and indeed, fragments of parts of products - increases the risk that such claims will interfere with otherwise lawful repair. ${ }^{103}$

Trademarks pose a similar threat, but one tempered by comparatively rigorous standards for protection. The law permits trademark protection for nonfunctional elements of product design to the extent that those elements demonstrate acquired distinctiveness - in other words, if consumers have come over time to associate those features with a single source of goods. As Grinvald and Tur-Sinai note, a Ford grille and a Volvo taillight have obtained product design trade dress protection. ${ }^{104} \mathrm{~A}$ car may function with an aftermarket grille or taillight, but in in the absence of available authentic parts, the aesthetic sacrifice would steer many customers to authorized repair providers, like local dealers.

96. See Koebler, supra note 13.

97. See Joshua D. Sarnoff, White Paper on Protecting the Consumer Patent Law Right of RePair AND the Aftermarket For Exterior Motor Vehicle RePAir PARTs: The PARTS ACT, S. 812; H.R. 1879, 115TH CONGRESS 4 (2017), https://papers.ssrn.com/sol3 /papers.cfm?abstract_id=3082289 [https://perma.cc/B2TS-TYNZ]; see also Sarah Burstein, Is Design Patent Examination Too Lax?, 33 Berkeley Tech. L.J. 607, 608 (2018); Sarah Burstein, The Patented Design, 83 TENN. L. REV. 161, 207-08 (2015) (noting that the patented design should be conceptualized as the design as applied to a particular type of product, while defining product as "something sold by an enterprise to its customers").

98. Auto. Body Parts Ass'n v. Ford Glob. Techs., L.L.C., 930 F.3d 1314 (Fed. Cir. 2019), cert. denied, 140 S. Ct. 1298 (2020) (mem.).

99. Id. at 1319.

100. Id.

101. Id. at $1322-23$.

102. Id. at 1325 .

103. See SARNOFF, supra note 97, at 4-5; The Patented Design, supra note 97, at 229.

104. Grinvald \& Tur-Sinai, supra note 75, at 116-17. 
Firms also deploy trademark law by seizing imported parts. Since repair providers often cannot acquire parts directly from device makers, they are forced to rely on the gray market. These parts are sourced in a variety of ways, but generally take advantage of the complex global supply chains that firms like Apple rely on. When Apple contracts with manufacturers to build screens, batteries, or other components, some of those parts end up in the hands of third-party repair providers. Some are lost or stolen from production lines and resold. Others fail diagnostic tests, only to be refurbished and resold. Others are copies of original parts produced by third parties. ${ }^{105}$ And still others intermingle third-party and original components. ${ }^{106}$

In order to invoke trademark law to clamp down on the gray market, Apple includes its logo on internal parts like batteries, processors, and cables. Most consumers never set eyes on these internal components and almost certainly don't take notice of the logos, some no bigger than a grain of rice. ${ }^{107}$ But even if they did, the resale of authentic goods bearing trademarks is generally lawful, whether those goods are new or refurbished. ${ }^{108}$ So long as refurbished goods are not presented to consumers as new, the first sale doctrine permits their resale. ${ }^{109}$ Nonetheless, companies like Apple rely on the ambiguous origins of some gray market goods to seize lawful parts imported by repair providers. And because U.S. law allows for border seizures of allegedly infringing goods, Apple can rely on nonjudicial processes that entail little due process or substantive oversight. The company has relied on the Department of Homeland Security to seize imports of replacement parts. For example, replacement iPhone screens featuring an authentic Apple flex cable bearing the company's logo were seized when Jessa Jones, a prominent repair professional, tried to import them. ${ }^{110}$ Similarly, DHS seized authentic Apple batteries shipped to Louis Rossman, an outspoken independent repair provider. ${ }^{111}$ Apple has

105. Jason Koebler, Apple Sued an Independent iPhone Repair Shop Owner and Lost, VICE (Apr. 13, 2018, 12:03 PM), https://www.vice.com/en_us/article/a3yadk/apple-sued-an -independent-iphone-repair-shop-owner-and-lost [https://perma.cc/LUY7-FYGE].

106. Jason Koebler, DHS Seizes Aftermarket iPhone Screens from Prominent Right-toRepair Advocate, VICE (May 11, 2018, 4:26 PM), https://www.vice.com/en_us/article/evk4wk /dhs-seizes-iphone-screens-jessa-jones [https://perma.cc/SU8T-78TJ].

107. Id.; see also iPhone XS and XS Max Teardown, IFIXIT (Sept. 21, 2018), https://www.ifixit.com/Teardown/iPhone+XS+and+XS+Max+Teardown/113021

[https://perma.cc/AY67-QM6E].

108. Champion Spark Plug Co. v. Sanders, 331 U.S. 125, 129-30 (1947); Nitro Leisure Prods., L.L.C. v. Acushnet Co., 341 F.3d 1356, 1361-62 (Fed. Cir. 2003). Under U.S. trademark law, imported goods that are materially different from those sold under the same mark in the United States can be deemed infringing. See Societe Des Produits Nestle, S.A. v. Casa Helvetia, Inc. 982 F.2d 633, 641 (1st Cir. 1992).

109. Nitro Leisure Prods., L.L.C., 341 F.3d at 1362.The use of genuine Apple parts bearing the company's mark can be distinguished from cases in which a trademark is added to a thirdparty replacement part. See, e.g., Rolex Watch U.S.A., Inc. v. Agarwal, No. CV 12-06400, 2012 WL 12886444, at *1 (C.D. Cal. Dec. 17, 2012).

110. Koebler, supra note 106.

111. Matthew Gault \& Jason Koebler, DHS Seized Aftermarket Apple Laptop Batteries from Independent Repair Expert Louis Rossman, VICE (Oct. 19, 2018, 2:25 PM), https://www.vice.com/en_us/article/a3ppvj/dhs-seized-aftermarket-apple-laptop-batteries -from-independent-repair-expert-louis-rossman [https://perma.cc/WAG8-UK6C]. 
relied on similar strategies throughout the world with varying degrees of success. ${ }^{112}$

Finally, trade secrets offer firms yet another legal mechanism to frustrate repair. As discussed above, device makers are keen to keep all sorts of information out of the hands of consumers and repair providers. Service manuals, diagnostics, schematics, and know-how related to repair techniques are among the kinds of information firms insist are valuable secrets. From televisions ${ }^{113}$ to ventilators, ${ }^{114}$ device makers have asserted trade secrets to increase the cost and inconvenience of independent repair. And in the legislative debates surrounding repair, firms often make vague, broad, and largely unsubstantiated assertions about the potential risks to unspecified secrets that they argue would be subject to mandatory disclosure. In judging the merits of such claims, the degree to which the information contained in these documents is already widely known, published, readily ascertainable, or has been uncovered through reverse engineering is crucial. ${ }^{115}$ If so, these assertions are not designed to protect valuable secrets, but-like the rest of the strategies outlined above - to impede lawful repair.

\section{LEGISLATING REPAIR}

In response to these varied and persistent efforts to hamper repair, a number of legislative changes have been proposed. At the federal level, the Promoting Automotive Repair, Trade, and Sales (PARTS) Act was introduced in 2017. ${ }^{116}$ The bill would have created a new defense to design patent infringement claims exempting the making, selling, or importing of exterior components of motor vehicles for repair purposes. ${ }^{117}$ But the PARTS Act stalled in committee. An earlier effort to eliminate restrictions on repair, the Motor Vehicle Owners Right to Repair Act, was first proposed in 2001. ${ }^{118}$ The most recent version, introduced in 2011, would have required carmakers to provide owners and service providers information, tools, and equipment necessary "to diagnose, service, maintain, or repair the motor vehicle." 119 Despite these repeated efforts, federal right to repair legislation failed to gain traction.

But in 2012, Massachusetts enacted an automotive repair bill that significantly shaped the national conversation. It required manufacturers of motor vehicles to "make available for purchase by owners ... and by independent repair facilities the same diagnostic and repair information" as well as "all diagnostic repair tools" made

112. Koebler, supra note 105.

113. Toshiba insists its repair manuals are available only to authorized parties under strict confidentiality agreements. See Letter from John Ryan to Tim Hicks, WIRED (July 31, 2012), https://www.wired.com/wp-content/uploads/blogs/opinion/wp-content/uploads/2012/11 /toshiba_timhicks_takedownletter.jpeg [https://perma.cc/TV8R-LBY4].

114. Koebler, supra note 13.

115. See Unif. Trade Secrets Act $\S 1$ (Nat'L Conf. Comm'rs on Unif. State L. 1985); see also DVD Copy Control Ass'n v. Bunner, 10 Cal. Rptr. 3d 185, 251 (Ct. App. 2004).

116. S. 812, 115th Cong. (2017); H.R. 1879, 115th Cong. (2017).

117. S. 812; H.R. 1879.

118. H.R. 2735, 107th Cong. (2001).

119. H.R. 1449, 112th Cong. $\S 3$ (2011). 
available to dealers, on "fair and reasonable terms." 120 And car makers must also "provide access to their onboard diagnostic and repair information system . . . using an off-the-shelf personal computer" beginning with 2018 model year vehicles. ${ }^{121}$ Although the bill passed in July, a ballot initiative enacting similar right to repair obligations was already slated for the November 2012 election. Massachusetts voters overwhelmingly supported the initiative, with $86 \%$ voting in favor. ${ }^{122}$

The Massachusetts law soon had national implications. In January of 2014, industry associations representing automakers and repair providers entered into a nationwide agreement to operate under the terms of the Massachusetts legislation. ${ }^{123}$ This voluntary arrangement, however, does not operate with the force of law. It does not bind nonparties, and alleged violations are evaluated by a dispute resolution panel composed of members of the various trade associations and a mediator. ${ }^{124}$ Nor would this détente necessarily embrace efforts to expand the rights of vehicle owners and repair providers. Another ballot initiative slated for the 2020 Massachusetts election, for example, would expand manufacturers' obligations to include telematics datainformation about vehicle performance collected and wirelessly transmitted to manufacturers. ${ }^{125}$ Under the proposal, manufacturers would have to make this realtime data available to vehicle owners and independent repair shops. ${ }^{126}$

Beyond its implications for vehicle repair, the Massachusetts automotive repair law has served as the template for a broader, nationwide effort to enshrine consumers' right to repair in state law. Building off the success of that effort, a coalition of policy advocates, repair professionals, tinkerers, and everyday consumers has pushed for legislation that would recognize the right to repair consumer electronics - not only smartphones, laptops, and televisions, but also household appliances, wearable technology, farm equipment, and medical devices, to offer just a few examples. In 2014, the South Dakota legislature considered the first of these bills. ${ }^{127}$ Just five years later, right to repair bills were introduced in

120. H. 4362, 187th Gen. Ct. (Mass. 2012).

121. $I d$.

122. 2012 - Statewide - Question 1, MAss. EleCtion Statistics, https://electionstats.state .ma.us/ballot_questions/view/6811 [https://perma.cc/RC6H-HQ5W]. To reconcile disparities between the ballot initiative and the House bill, another bill was passed in 2013. H.3757, 188th Gen. Ct. (Mass. 2013).

123. See Memorandum of Understanding Among Kathleen Schmatz, President \& CEO, Auto. Aftermarket Indus. Ass'n, Ray Pohlman, President, Coal. for Auto Repair Equal., Mitch Bainwol, President \& CEO, All. Auto. Mfrs., and Michael Stanton, President \& CEO, Ass'n Glob. Automakers (Jan. 15, 2014) https://www.nastf.org/files/public/OtherReference/MOU

_SIGNED_1_15_14.pdf [https://perma.cc/6Q6K-S63A]. In exchange for their promise to abide by the substantive terms of the law, carmakers extracted a promise from repair providers to withdraw support and funding for similar bills in other states. Id. Notably, Tesla is not a signatory to the MOU.

124. Id. See also Adrian Ma, Your Car Talks to the Manufacturer. Advocates Want It to Talk to You, Too, WBUR (Aug. 6, 2019), https://www.wbur.org/bostonomix/2019/08/06/right-to -repair-ballot-measure [https://perma.cc/RG9S-QFB5].

125. See Grinvald \& Tur-Sinai, supra note 10, at 28-29.

126. $I d$.

127. S.B. 136, 2014 Legis. Assemb., 89th Sess. (S.D. 2014). 
twenty statehouses across the country. ${ }^{128}$

These bills closely track a model proposal from the Repair Association, an umbrella organization representing repair providers, advocates, hobbyists, and environmental activists. ${ }^{129}$ Its key provision would require manufacturers of digital electronics to "make available, for purposes of diagnosis, maintenance, or repair, to any independent repair provider, or to the owner of digital electronic equipment ... . on fair and reasonable terms, documentation, parts, and tools, inclusive of any updates to information or embedded software." ${ }^{30}$ And for equipment protected by electronic security measures, manufacturers must "make available . . . any special documentation, tools, and parts needed to reset the lock or function when disabled in the course of diagnosis, maintenance, or repair."131

The right to repair movement has attracted a diverse constellation of supporters, including the American Farm Bureau, ${ }^{132}$ the Illinois Health and Hospital Association, ${ }^{133}$ the New York Times editorial board, ${ }^{134}$ Bernie Sanders, ${ }^{135}$ and Elizabeth Warren. ${ }^{136}$ Despite this support and the movement's considerable success in persuading state legislators to introduce these bills, none have been enacted yet. But given the intense anti-repair lobbying the bills have provoked, that failure is hardly surprising. The companies condemning right to repair proposalsoccasionally publicly, but more often behind closed doors - include Apple, AT\&T, Caterpillar, Dyson, GE Healthcare, John Deere, Lexmark, LG, Medtronic, Microsoft,

128. Those states included: California, Georgia, Hawaii, Illinois, Indiana, Massachusetts, Minnesota, Missouri, Montana, North Dakota, Nevada, New Hampshire, New Jersey, New York, Oregon, South Dakota, Vermont, Virginia, Washington, and West Virginia. California Becomes 20th State in 2019 to Consider Right to Repair Bill, U.S. PIRG (Mar. 18, 2019), https:/uspirg.org/news/usp/california-becomes-20th-state-2019-consider-right-repair-bill [https://perma.cc/J42Q-R5TY]. At least one more state has introduced a bill in 2020. Kevin Purdy, Right to Repair Is Gaining Ground in 2020, IFIXIT (Feb. 14, 2020), https://www.ifixit .com/News/35606/right-to-repair-is-gaining-ground-in-2020 [https://perma.cc/M4EJ-Z6P4].

129. About Us, REPAIR Ass'N, https://repair.org/association [https://perma.cc/JBU6 -4QVW].

130. Model State Right-to-Repair Law, REPAIR Ass'N, (Jan. 22, 2020), https://repair.org/s /Right-to-repair-model-state-law-updated-1-22-20.docx [https://perma.cc/39P2-A3D8].

131. Id.

132. Kevin O'Reilly, American Farm Bureau Reaffirms Support for Right to Repair, U.S. PIRG (Jan. 22, 2020), https://uspirg.org/blogs/blog/usp/american-farm-bureau-reaffirmssupport-right-repair [https://perma.cc/A2VW-HB7Y].

133. Agam Shah, Who Has a Right to Repair Your Farm or Medical Tools?, ASME, (Apr. 16, 2019), https:/www.asme.org/topics-resources/content/has-right-repair-farm-medical -tools [https://perma.cc/XEG7-LK6R].

134. N.Y. Times Ed. Bd., It's Your iPhone. Why Can't You Fix It Yourself?, N.Y. TIMES (Apr. 6, 2019), https://www.nytimes.com/2019/04/06/opinion/sunday/right-to-repair -elizabeth-warren-antitrust.html [https://perma.cc/RS3H-L88V].

135. Matthew Gault, Bernie Sanders Calls for a National Right-to-Repair Law for Farmers, VICE (May 5, 2019, 5:48 PM), https:/www.vice.com/en_us/article/8xzqmp/bernie -sanders-calls-for-a-national-right-to-repair-law-for-farmers [https://perma.cc/6V73-393C].

136. Team Warren, Leveling the Playing Field for America's Family Farmers, MEDIUM (Mar. 27, 2019), https://medium.com/@teamwarren/leveling-the-playing-field-for-americas -family-farmers-823d1994f067 [https://perma.cc/B2YW-ED2U]. 
Toyota, Verizon, and Wahl. ${ }^{137}$ This partial list excludes trade associations and industry groups like the Entertainment Software Association (ESA) ${ }^{138}$ and AdvaMed, among others, that lobby against repair bills on behalf of their members. ${ }^{139}$

Aside from predictable concerns over intellectual property, these firms and their trade associations offered an assortment of alarmist arguments to undermine support for right to repair legislation. Apple told Nebraska lawmakers that the bill would turn the state into a "Mecca for bad actors," predicting that hackers and other nefarious figures would flock to the state to exploit consumers. ${ }^{140}$ And in California, it warned that consumers were at risk of physical injury if they attempted to swap out their iPhone batteries. ${ }^{141}$ Wahl cautioned that repair of its hair clippers could cause fires, while Dyson and LG issued unfounded warnings that the right to repair could put consumers' personal safety at risk by allowing repair personnel in their homes who had not cleared background checks. ${ }^{142}$

More plausibly, medical device manufacturers and their trade groups have raised health and safety concerns around repair. AdvaMed, a medical device trade group, warned Massachusetts lawmakers that the state's proposed repair legislation "could result in maintenance and repairs of medical devices being performed by untrained personnel, and that inappropriate replacement parts may be used." ${ }^{143}$ Likewise, GE Healthcare's letter to New Hampshire legislators claimed that state's bill would "require manufacturers of FDA Class I and II medical devices to provide proprietary diagnostic and repair information to unregulated service providers." 144 The implication is clear: third parties cannot be trusted to repair medical devices. But according to a recent Food and Drug Administration (FDA) report, "the continued availability of third party entities to service and repair medical devices is critical to

137. See Jason Koebler, The Right to Repair Battle Has Come to Silicon Valley, VICE (Mar. 7, 2018, 5:25 PM), https://www.vice.com/en_us/article/8xdp94/right-to-repair -california-bill [https://perma.cc/JFE3-2MNR] [hereinafter Right to Repair Battle]; Koebler, supra note 30; Jason Koebler, Appliance Companies Are Lobbying to Protect Their DRMFueled Repair Monopolies, VICE (Apr. 25, 2018, 9:00 AM), https://www.vice.com/en_us /article/vbxk3b/appliance-companies-are-lobbying-against-right-to-repair [https://perma.cc /SP5T-ASGR] [hereinafter Appliance Companies]; Koebler, supra note 13; Olivia Solon, A Right to Repair: Why Nebraska Farmers Are Taking on John Deere and Apple, GUARDIAN (Mar. 6, 2017, 6:00 AM), https://www.theguardian.com/environment/2017/mar/06/nebraska -farmers-right-to-repair-john-deere-apple [https://perma.cc/5L8C-8849].

138. Gault, supra note 30.

139. Koebler, supra note 13.

140. Michael Hiltzik, Column: How Apple and Other Manufacturers Attack Your Right to Repair Their Products, L.A. Times (Nov. 16, 2018, 7:30 AM), https://www.latimes.com /business/hiltzik/la-fi-hiltzik-right-repair-20181116-story.html [https://perma.cc/7T5K -DHP6].

141. Jason Koebler, Apple Is Telling Lawmakers People Will Hurt Themselves if They Try to Fix iPhones, VICE (Apr. 30, 2019, 3:56 PM), https://www.vice.com/en_us/article /wjvdb4/apple-is-telling-lawmakers-people-will-hurt-themselves-if-they-try-to-fix-iphones [https://perma.cc/8XUX-RN52].

142. Appliance Companies, supra note 137.

143. Koebler, supra note 13.

144. Id. 
the functioning of the U.S. healthcare system." 145 As the FDA explained, many thirdparty repair providers deliver "high quality, safe, and effective servicing of medical devices."146 The importance of third-party repair was illustrated when Los Angeles received 170 broken ventilators in the midst of the COVID-19 crisis. Rather than shipping them back to the manufacturer, California relied on Bloom Energy, a firm that makes fuel-cell energy generators, which successfully repaired the ventilators in a matter of days. ${ }^{147}$

The views of device makers have certainly been heard in the repair debate, as have those of independent repair providers. And while organizations like U.S. PIRG have advocated for repair as essential to the public interest, the actual views of everyday consumers have been largely absent from the ongoing policy debate over the right to repair. Since most consumers will only occasionally fix a broken device even in the most repair-friendly of environments, their interests in the outcome of this debate are considerably more diffuse than either device makers or repair providers. But collectively, the beliefs, expectations, and practices of consumers are crucial in evaluating both pending state right to repair proposals and the broader legislative and regulatory repair agenda. The next Part reveals those views.

\section{SURVEYING REPAIR}

The case for legislative intervention in repair markets depends on two key propositions. First, it asserts that legal and practical constraints limit the availability and increase the cost of repair. As Part I detailed, those restrictions are very real. Second, it assumes that changes in the law will influence consumer behavior by lowering effective barriers to repair. But the degree to which lower prices and wider availability of repair will result in an uptick in consumer or third-party repair hinges on consumer expectations and preferences surrounding the reparability of the products they buy. If instead, consumers view their devices as disposable "throwaways" - as one New Hampshire legislator referred to smartphones - then repair legislation is unlikely to have much effect. ${ }^{148}$

In order to assess how consumers understand and relate to repair, I conducted a web-based survey of internet users $(\mathrm{N}=838)$ in $2020 .{ }^{149}$ The sample was broadly

145. U.S. Food \& Drug Admin., FDA Report on the Quality, Safety, AND EFFECTIVENESS OF SERVICING OF MEdicAl DeVicEs (2018), https://www.fda.gov/media /113431/download [https://perma.cc/43BV-EMHG].

146. $I d$.

147. Samantha Masunaga, California Companies Jump in to Supply Ventilators Needed in Coronavirus Fight, L.A. Times (Mar. 23, 2020, 11:41 AM), https://www.latimes.com/business /story/2020-03-23/coronavirus-california-companies-medical-supplies [https://perma.cc /C6H8-HLMP].

148. Timothy Geigner, Totally In-Touch NH Lawmaker Blocks Device Repair Bill, Tells Constituents to Just Buy New \$1k Phones, Techdirt (Nov. 1, 2019, 7:39 PM), https://www.techdirt.com/articles/20191029/07142043278/totally-in-touch-nh-lawmaker -blocks-device-repair-bill-tells-constituents-to-just-buy-new-1k-phones.shtml [https://perma.cc/Y3XF-TSNG].

149. The survey was administered using the internet survey platform Qualtrics. The panel of respondents was drawn from an initial pool of 7500 internet users who were invited to 
representative of the U.S. population with respect to sex, ${ }^{150}$ age, ${ }^{151}$ and income ${ }^{152}$ according to census data. In addition, the survey collected information on respondents' races, ${ }^{153}$ education levels, ${ }^{154}$ as well as their tendencies to buy the latest electronic devices. ${ }^{155}$

The survey asked a series of five screening questions to limit respondents to those who were in the market for one of five categories of electronic devices. Specifically, those questions asked whether the respondent purchased in the prior twelve months or was considering purchasing in the next twelve months: a smartphone, tablet, smart

participate in the survey. From that initial pool, 2027 participants began the survey, and 838 successfully completed it. 1168 respondents were excluded for failing to meet demographic criteria or screening questions. Twenty-one incomplete responses were also excluded.

150. The panel was $49 \%$ male and $51 \%$ female. This matches 2010 census data. See Lindsay M. Howden \& Julie A. Meyer, U.S. Census Bureau, C2010BR-03, Age And SeX COMPOSITION: 20102 (2011) https://www.census.gov/prod/cen2010/briefs/c2010br-03.pdf.

151. The age distribution of the survey panel was: eighteen to twenty-four, $14 \%$; twentyfive to thirty-four, $17 \%$; thirty-five to forty-four, $18 \%$; forty-five to fifty-four, $17 \%$; fifty-five to sixty-four, $13 \%$; sixty-five or older, $21 \%$. This sample is well aligned with 2019 census estimates. See U.S. Census Bureau, Annual Estimates of the Resident Population for Selected Age Groups by Sex For the United States (2019) https://www.census.gov/data /tables/time-series/demo/income-poverty/cps-hinc/hinc-01.html [https://perma.cc/2S2F -MFCE].

152. The distribution of the panel by household income was: less than $\$ 24,999,14 \%$; $\$ 25,000$ to under $\$ 49,999,23 \%$; $\$ 50,000$ to under $\$ 74,999,19 \% ; \$ 75,000$ to under $\$ 99,999$, $13 \%$; $\$ 100,000$ to under $\$ 149,999,15 \%$; over $\$ 150,000,14 \%$. This closely tracks 2018 census data. See U.S. Census Bureau, Selected Characteristics of Households by Total MoneY INCOME (2019), https://www.census.gov/data/tables/time-series/demo/income -poverty/cps-hinc/hinc-01.html [https://perma.cc/JG9M-VZDF]. Annual incomes below $\$ 25,000$ are underrepresented in the survey panel. This likely reflects the expense of many of the devices targeted in the screening questions.

153. The distribution of the panel by race was: White/Caucasian, 77\%; African American, $10 \%$; Hispanic, 6\%, Asian, 4\%; Native American, 2\%; Pacific Islander, less than $1 \%$; Other $2 \%$. African Americans are somewhat underrepresented, but the sample is otherwise broadly representative of the U.S. population. See KAREN R. Humes, Nicholas A. JoneS \& RoberTo R. Ramirez, U.S. Census Bureau, C2010BR-02, Overview of RaCe and Hispanic Origin: 20104 (2011), https://www.census.gov/prod/cen2010/briefs/c2010br-02.pdf [https://perma.cc /H6US-SL4H].

154. The distribution of the panel by education level was: Less than High School, $1 \%$; High School/GED, 17\%; Some College, 26\%; 2-year College Degree, 14\%; 4-year College Degree, 24\%; Master's Degree, 14\%; Doctoral Degree, 1\%; Professional Degree (JD, MD), 2\%. The survey sample was more highly educated than the overall U.S. population, with those with a high school education or less considerably underrepresented. See Educational Attainment in

the United States: 2018, U.S. CENSUS BuREAU (Feb. 21, 2019), https://www.census.gov/data/tables/2018/demo/education-attainment/cps-detailed-tables .html [https://perma.cc/FD4C-YSMT].

155. Respondents were asked, "How would you describe your use of new technologies?" Their responses were as follows: I am usually the first person in my social circle to buy the latest devices, 30\%; I tend to wait a while before buying the latest devices, 50\%; I don't have strong preferences about buying the latest devices, $14 \%$; I tend to avoid buying the latest devices, $2 \%$; I almost never buy the latest devices, $3 \%$. 
speaker, digital camera, or smart refrigerator. ${ }^{156}$ The order of these questions was randomized. If a respondent answered "Yes" to one of the questions, they were then asked a series of follow-up questions about that device. ${ }^{157}$ Aside from the device at issue, those five sets of questions were identical. After completing the devicespecific questions, each respondent was asked about their experience repairing or attempting to repair a smartphone or tablet. Finally, the survey asked respondents about their familiarity with the "right to repair" and the degree to which they support legislation designed to secure it.

\section{A. Expectations of Repair}

The first set of device-specific questions was designed to measure the degree to which consumers expect and value the ability to repair the products they buy. The responses reveal high expectations of reparability across device categories. They further reveal the extent to which consumers are surprised, angered, and even betrayed to learn that device makers may limit their choices around the repair of products they have purchased.

Respondents were asked: Do you agree or disagree with the following statement? "If I purchase a [device], I have the right to repair it myself or to take it to the repair shop of my choice." As Figure 1 illustrates, the vast majority of respondents agreed with this sentiment, and $60 \%$ strongly agreed. The results for smartphones and tablets were nearly indistinguishable with the overall responses. Notably, digital camera purchasers expressed significantly stronger expectations for repair. $75 \%$ strongly agreed, and another $18 \%$ somewhat agreed. Digital cameras, which first appeared in the 1990s, predate many of the recent efforts to restrict repair, perhaps explaining consumers' stronger expectations. In contrast, two relatively recent product categories - smart speakers and refrigerators - elicited less overwhelming responses. But even in those cases, sizable majorities expected freedom to repair their devices as they saw fit.

156. These devices were chosen for several reasons. First, they reflect a range of prices from less than a hundred to thousands of dollars. Second, some are nearly ubiquitous, while others are relatively uncommon. Third, they are all devices consumers experience difficulty repairing to some degree.

157. The survey was designed to keep these groups roughly equal in size: 169 for smartphones; 169 for digital camera; 168 for smart speakers; 168 for tablets; and 164 for smart refrigerators. Respondents who answered "No" to all five questions were disqualified. 


\section{Figure 1: Right to Repair}
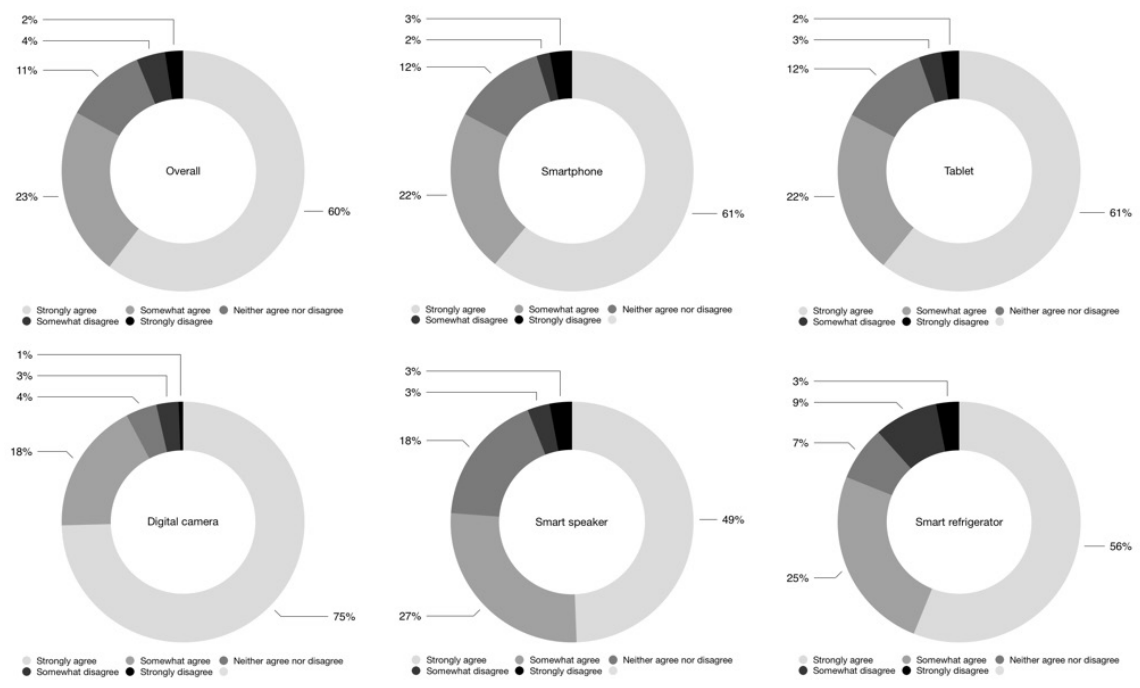

As an alternative measure, respondents were asked: If you learned that the manufacturer of your [device] limited your ability to repair it yourself or have it repaired, how would you feel? Not surprisingly, majorities of respondents indicated that they would be either "very surprised" or "somewhat surprised." However, as seen in Figure 2, the levels of surprise were markedly lower than the measure of expectation reported above. In part, this may indicate that consumers regard device makers with some degree of skepticism. After revelations of secret microphones, ${ }^{158}$ throttled processors, ${ }^{159}$ and defeat devices, ${ }^{160}$ there is very little that would surprise some consumers.

158. Sidney Fussell, The Microphones That May Be Hidden in Your Home, ATLANTIC (Feb. 23, 2019), https://www.theatlantic.com/technology/archive/2019/02/googles-home-securitydevices-had-hidden-microphones/583387 [https://perma.cc/G5NE-6CLE].

159. See Robertson, supra note 49.

160. Bill Chappell, 11 Million Cars Worldwide Have Emissions Defeat Device,' Volkswagen Says, NPR (Sept. 22, 2015, 6:59 AM), https://www.npr.org/sections/thetwo-way /2015/09/22/442457697/11-million-cars-worldwide-have-emissions-problem-volkswagen -says [https://perma.cc/R8G5-XPLR]. 
Figure 2: Manufacturer Limitations
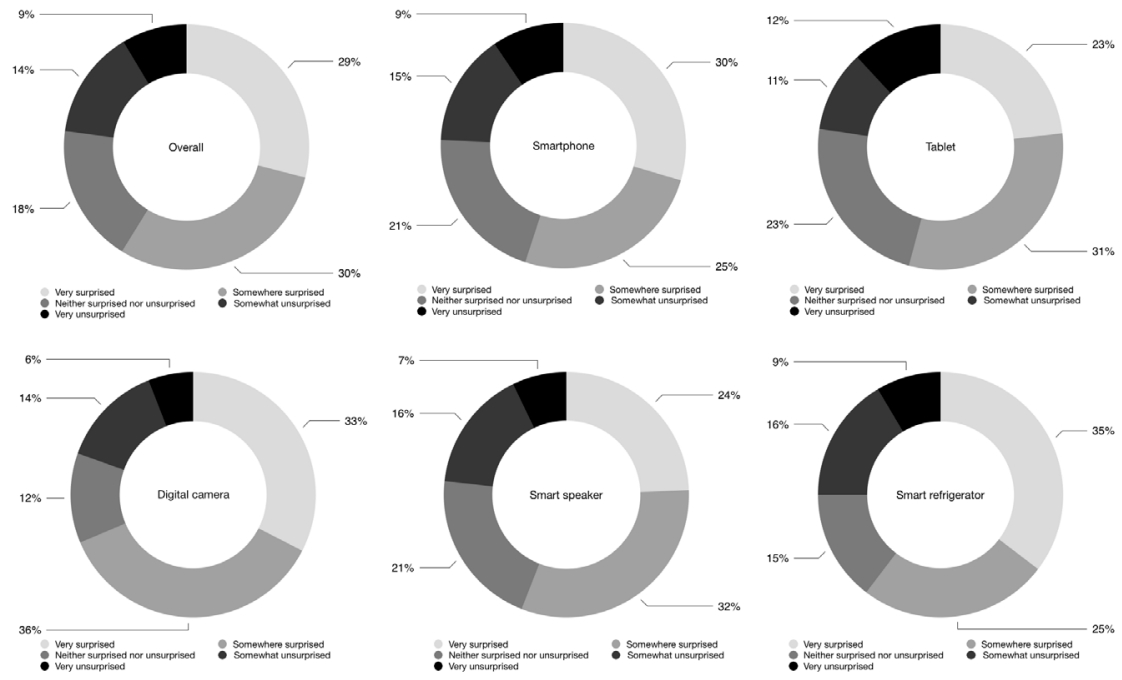

Respondents were also given an opportunity to describe in their own words how they would feel if they learned of restrictions on the repair of their device. They were asked: How else would you feel if you learned that the manufacturer of your [device] limited your ability to repair it or have it repaired? Consistent with results described above, these open-ended responses were quite critical of such restrictions $67 \%$ were negative (557), and only $9 \%$ were positive (79). The remaining $24 \%$ were neutral, unclear, or non-responsive (202). ${ }^{161}$

The negative sentiments included a number of respondents who felt: "angry" (63), "upset" (60), "disappointed" (37), "frustrated" (28), "annoyed" (26), "mad" (22), "cheated" (17), and "pissed" (9). Those were in addition to respondents who described feeling "conned," "deceived," "scamm[ed]," and "swindled." Other responses focused on the ways in which repair restrictions interfere with consumer autonomy. One respondent noted, "I don't think [manufacturers] have any right to tell me what I can do with it after I purchase it." Another was concerned that "the manufacturer is impacting my freedom to do with what I want a product that I legally own."

Among respondents who expressed positive reactions to repair restrictions, two themes emerged. First, several respondents believed that manufacturers have greater expertise and can ensure high-quality repairs. One noted that "specialized equipment inside . . . requires the manufacture's [sic] touch." As another put it, "the manufacturer knows more than I would or my local Joe to fix it." Second, several respondents expressed favorable views of limitations on repair to the extent necessary to keep the product under warranty, a worry the FTC has attempted to assuage by reminding firms that it is illegal to condition warranty coverage on the

161. All references to questions and responses in this Part refer to the survey conducted by the author from March 4-12, 2020. 
use of particular parts or service providers. ${ }^{162}$

\section{B. Materiality of Repair}

The next pair of questions was intended to measure the degree to which repair restrictions, if disclosed, are material to consumer decision-making. The first asked: If you knew the manufacturer limited your ability to repair a [device], would that affect your willingness to purchase that [device]? Overall, more than $70 \%$ of respondents indicated that restrictions on repair would make them either much less likely $(40 \%)$ or somewhat less likely $(32 \%)$ to purchase one of the five devices. These results were largely consistent across device types, as illustrated in Figure 3.

Figure 3: Materiality of Repair
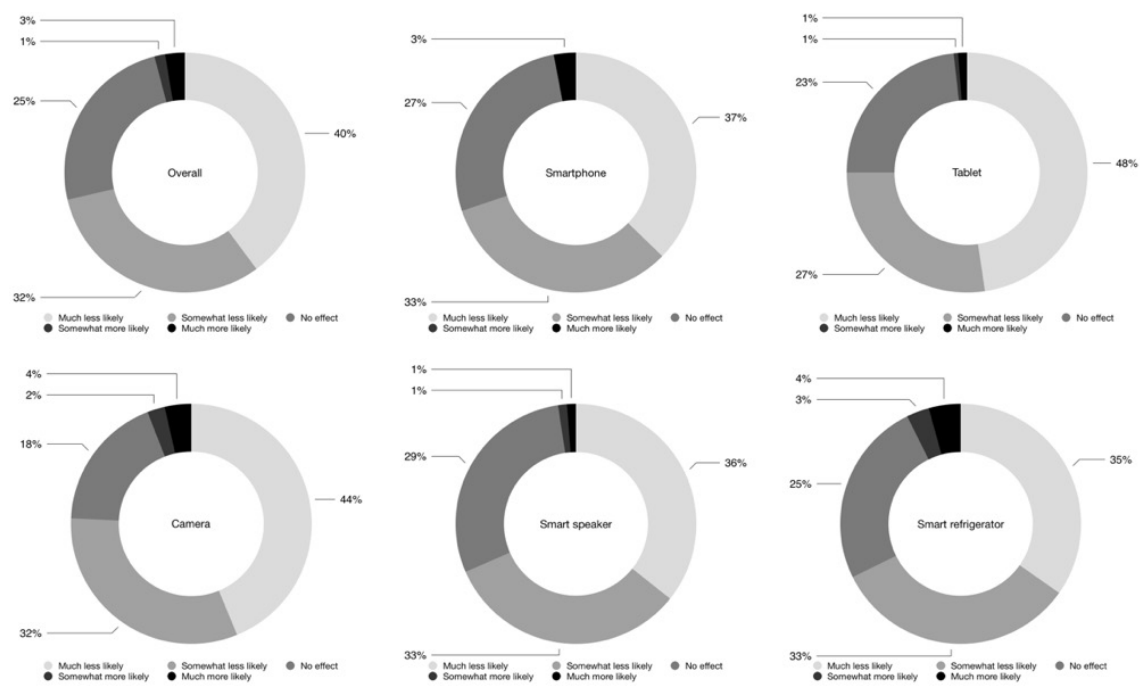

Materiality, however, is not simply a binary question of whether a consumer would make a purchase. It is also reflected in the price consumers are willing to pay for a product. So, respondents were also asked: If you knew the manufacturer limited your ability to repair a [device], would that affect the price you would be willing to pay for that [device]? Rather than ask for absolute numbers, given the considerable variation in price within and among these product categories, respondents were presented with comparative measures of their willingness to pay. And again, the vast

162. The Magnuson-Moss Warranty Act prohibits manufacturers that charge more than $\$ 5$ for a product from restricting repair of the devices covered by warranties. 15 U.S.C. $\S 2301$. But a recent study found that forty-five out of fifty appliance makers claimed to void warranties for unauthorized repairs. Nathan Proctor, Survey Finds 45 of 50 Companies Void Warranties for Independent Repair, U.S. PIRG (Oct. 11, 2018), https://uspirg.org/news/usp /survey-finds-45-50-companies-void-warranties-independent-repair [https://perma.cc/52VG -ZWTX]. 
majority indicated that they would pay less for a device burdened by repair restrictions, with $40 \%$ willing to pay "much less" and $30 \%$ willing to pay "somewhat less." As Figure 4 shows, those percentages were slightly lower for refrigerators, products that respondents perhaps assume are less likely to require repair.

Figure 4: Price Change
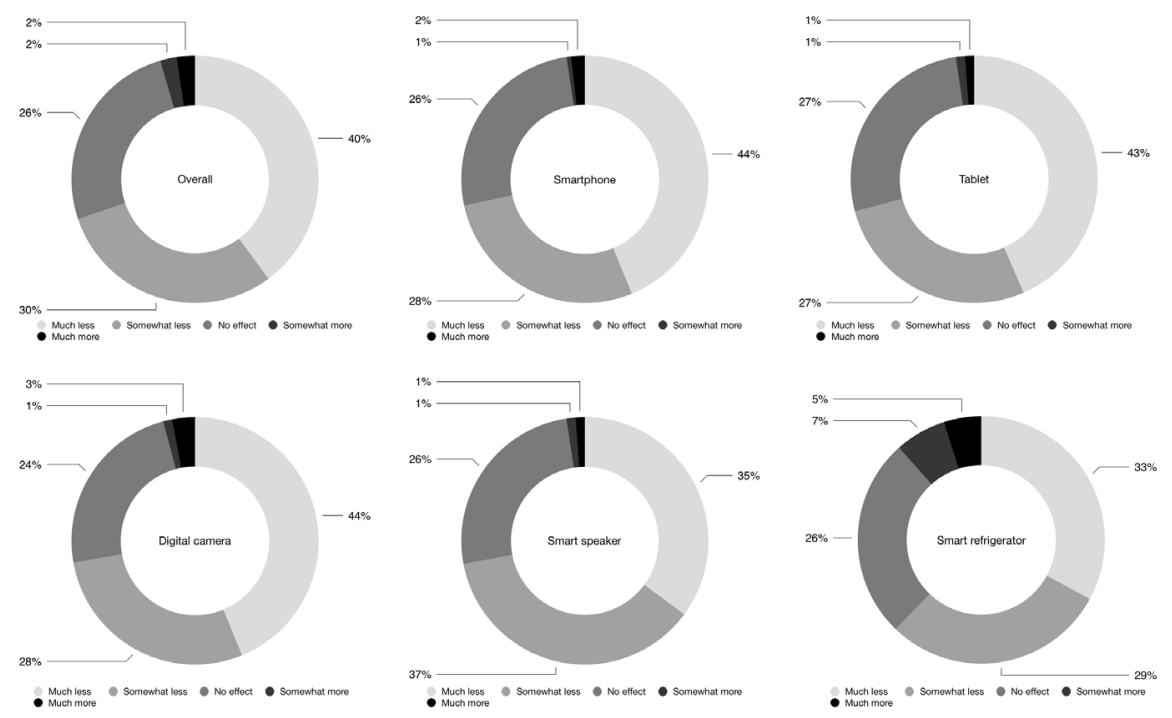

By both of these metrics, consumers not only have expectations of repair, but accurate information about repair restrictions will inform and shape their marketplace behavior.

\section{Experience with Repair}

The next set of questions focused on respondents' experience with repair. In order to maximize the sample, these questions focused exclusively on smartphones and tablets. Nearly all respondents (825) indicated that they owned a smartphone or tablet. Of those, $86 \%$ said they had "replaced, discarded, or recycled a smartphone or tablet" for one or more of the reasons below. Cracked screens and dead batteriestwo easily repairable problems - were by far the most prevalent reasons identified by respondents for discarding or replacing their devices. As Figure 5 illustrates, most devices are discarded because of the failure of physical components. 
Figure 5: Replacing, Discarding, or Recycling

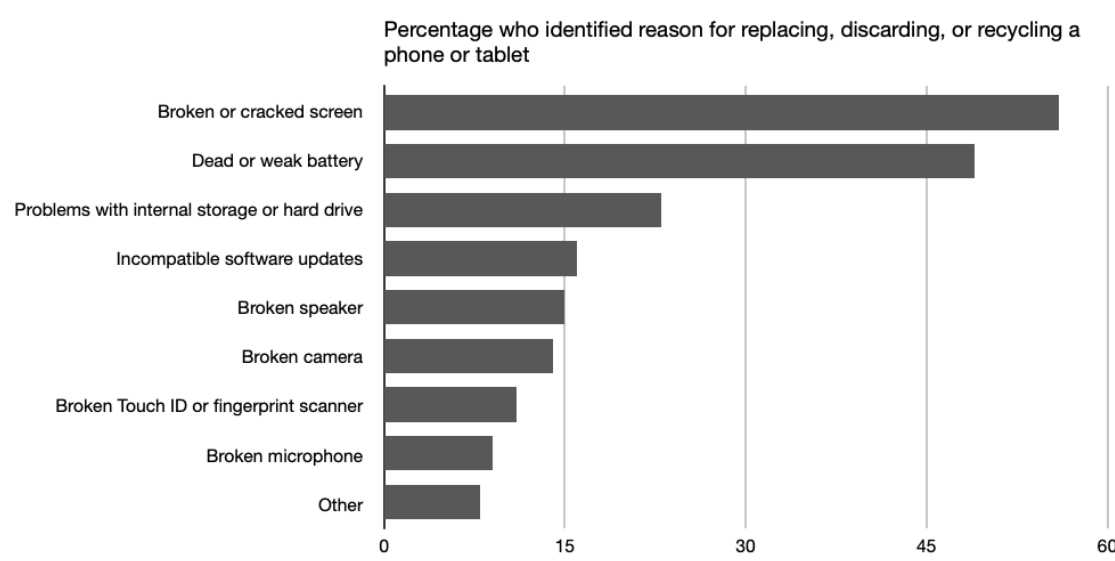

Interest in repair was high among respondents. Among respondents who had replaced, discarded, or recycled a smartphone or tablet, $92 \%$ had considered or attempted repairing it themselves or having it repaired. Half of respondents considered or attempted independent repair services. Slightly fewer, $48 \%$, considered or attempted manufacturer repair. And $44 \%$ considered or attempted self-repair. When asked to describe their experience, $52 \%$ said repairs were too expensive, and $24 \%$ reported that the necessary parts and tools were unavailable.

These responses suggest that consumers are open to and interested in repairing their devices. But cost and the availability of parts and tools are significant roadblocks. Right to repair laws would address both of these concerns. By mandating the availability of parts and tools, those laws would reduce the costs consumers and repair providers face in securing components. At the same time, by lowering barriers to entry, they would encourage a more competitive repair market, further driving down prices for repair services.

Respondents were also asked about their experience with trade-in programs. More than half, 54\%, reported that they had "received or been offered credit on a new device in exchange for trading in a damaged or broken smartphone or tablet." As Figure 6 illustrates, $78 \%$ of those respondents said they were "much more" or "somewhat more willing" to buy a new device in light of the trade-in offer. And 38\% reported that the trade-in offer reduced their interest in repairing their device. 
Figure 6: Consumer Considerations

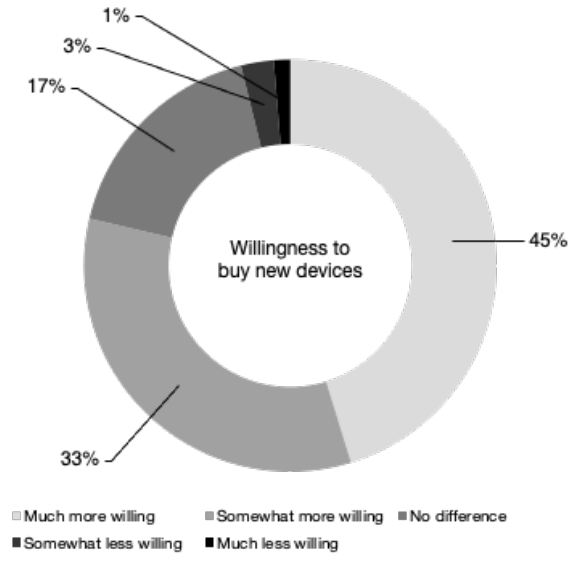

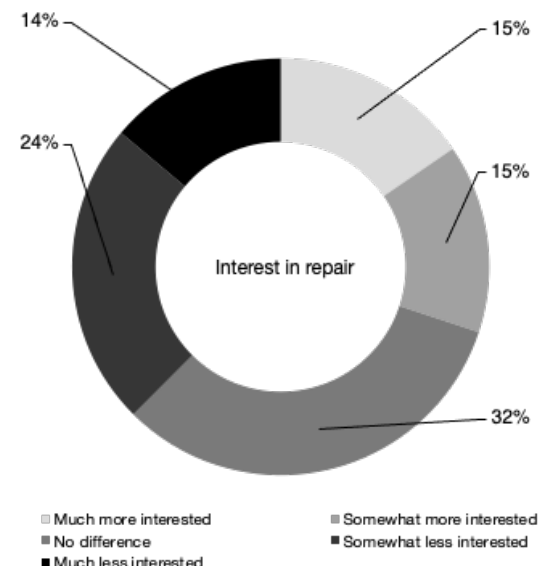

- Much less interested

\section{Support for Repair}

Finally, respondents were asked about their awareness of and support for the right to repair. Although the majority of respondents were not familiar with the right to repair, they overwhelmingly supported legislative interventions like those under consideration in statehouses around the country.

When asked: How familiar are you with the idea of the 'right to repair' electronic devices, appliances, and other consumer goods?, 52\% of respondents said they were "not at all familiar," and only $12 \%$ indicated they were "very familiar." Despite the low level of awareness of the right to repair as a concept or movement, support for legislation designed to help secure that right was overwhelmingly popular. As seen in Figure 7, 86\% of respondents - the same percentage of Massachusetts voters who favored that state's automotive repair law in 2012 - expressed support for "legal rules that require device makers to provide parts, tools, software updates, and documentation available to independent repair shops and consumers on reasonable terms." And nearly 60\% strongly supported them. For respondents who indicated they were "very familiar" with the right to repair, support was even higher, with $98 \%$ favoring the legislation. ${ }^{163}$

163. These results are consistent with a 2019 study of support for the right to repair among Canadians. See Innovative Research Grp., Right to Repair: National Online Omnibus Survey, Open Media (May 2019), https://openmedia.org/sites/openmedia.org/files/openmedia_right _to_repair_omnibus_questions_report___20190531.pdf [https://perma.cc/349E-BGB4]. More than $60 \%$ of U.S. survey respondents indicated they would favor the next President signing an executive order mandating the right to repair. David Dayen, The Day One Agenda Polls Pretty Well, AM. РRospect (Feb. 11, 2020), https://prospect.org/day-one-agenda /executive-authority-polls-pretty-well [https://perma.cc/6XLE-GXHC]. 


\section{Figure 7: Support for Right to Repair}
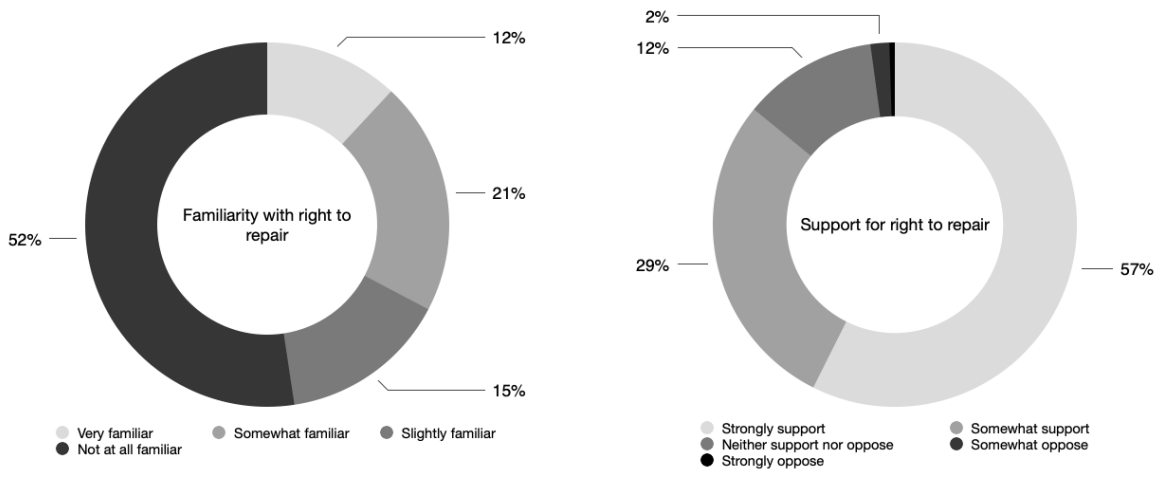

\section{IMPLICATIONS}

The survey results outlined above establish that right to repair legislation enjoys broad popular support that is likely to grow as consumers become more familiar with the issue. Beyond popular approval, the survey data also affirm the theory underlying legislative intervention in repair markets. The high costs of repairs and the limited availability of parts and tools are significant barriers. Mandating access for consumers and third-party repair providers would reduce prices, foster competition, and increase the prevalence of repair.

If made law, these bills would save consumers untold millions of dollars and spare the environment from some of the harms of rampant digital consumerism. ${ }^{164} \mathrm{But}$ these bills are not a cure-all. They are limited in scope and cannot be expected to address every impediment to repair. Overbroad interpretations of intellectual property rights will continue to plague repair providers. And design techniques hostile to repair will remain a source of ongoing frustration.

One important shortcoming of the pending bills is the absence of any affirmative obligation on the part of device makers to produce replacement parts. The model bill provides, "[n]othing in this section requires an original equipment manufacturer to make available a part if the part is no longer available to the original equipment manufacturer." 165 So, if a firm decides to phase out support for a product after only a couple of years, it is not required to make parts available to the third-party repair market. A more stringent approach would insist that firms supply parts for a specified period of time. California law, for example, already mandates seven years of support for products that cost $\$ 100$ or more, including supplying replacement parts. ${ }^{166}$

European regulators are taking an even more aggressive stance. In addition to an obligation to supply parts for up to ten years, new ecodesign rules require that

164. To take just one metric of those harms, the United Nations reported that in 2019 alone, global electronic waste totaled 53.6 million tons. VANESSA ForTi, CORnElis P. BALdÉ, Ruediger Kuehr \& Garam Bel, The Global E-Waste Monitor 2020: Quantities, Flows, AND THE CiRCular ECONOMY Potential 13 (2020).

165. Model State Right-to-Repair Law, supra note 130.

166. CAL. Civ. CODE $§$ 1793.03(b) (requiring manufacturers of electronics and appliances 
products be designed so that replacement parts can be installed using commonly available tools and without damaging the device. ${ }^{167}$ The first round of regulations applies to household appliances like refrigerators, washing machines, and dishwashers. ${ }^{168}$ But the European Commission has announced plans for another set of ecodesign rules to increase the reparability of phones, tablets, and laptops. ${ }^{169} \mathrm{Such}$ rules might even require companies to design phones and laptops with easily replaceable batteries. ${ }^{170}$

Rather than promote repair by merely increasing the accessibility of parts and encouraging competition, the European approach proactively shapes product design by insisting on devices built to facilitate repair. Given the size of the European market, manufacturers may apply these new standards globally. In much the same way, the Restriction of Hazardous Substances (RoHS) Directive shaped the design of electronics by regulating the use of heavy metals. ${ }^{171}$

Device makers would undoubtedly resist any regulatory intervention in the design process. They would note, accurately, that product design is a complex exercise that requires balancing and prioritizing a range of competing, interdependent considerations. Technical constraints limit functionality; competitive constraints limit price; design philosophies and conventions inform aesthetic choices; consumer tastes and trends affect a range of product attributes; and legal rules, from patents to products liability, layer additional constraints across all these dimensions. No doubt, legal obligations like those contemplated by the Ecodesign Directive introduce additional complexity into the design process. But durability and reparability are hardly unknown considerations for designers. These rules simply require them to prioritize those familiar considerations in order to meet clear objectives.

Nor would an approach that intercedes in the design of consumer products to protect the interests of consumers and the environment be unheard of in the United States. Federal law, for example, has mandated seat belts in motor vehicles since

with wholesale prices of $\$ 100$ or more with express warranties to "make available to service and repair facilities sufficient service literature and functional parts"). Such a requirement undoubtedly increases costs for device makers, some of which may be passed onto consumers indirectly. To the extent such price increases internalize the costs of device production and disposal, they should be celebrated. The costs of legacy support may also slow the introduction of new products, but a reduction in the frequency of minor, incremental improvements meant to drive product upgrade cycles may be a reasonable tradeoff for achieving a corresponding reduction in the environmental harm of digital consumerism.

167. The New Ecodesign Measures Explained, EuROPEAN COMM'N (Oct. 1, 2019), https://ec.europa.eu/commission/presscorner/detail/en/qanda_19_5889 [https://perma.cc /8XHQ-EGV5].

168. $I d$.

169. Questions and Answers: A New Circular Economy Action Plan for a Cleaner and More Competitive Europe, EuROPEAN COMM'N (Mar. 11, 2020), https://ec.europa.eu /commission/presscorner/detail/en/qanda_20_419 [https://perma.cc/K89P-D5WB].

170. Charlie Wood \& Sophia Ankel, Europe May Force Makers of Smartphones, Tablets and Wireless Earphones to Install Easily Replaceable Batteries, Bus. Insider (Feb. 27, 2020, 12:09 PM), https://www.businessinsider.com/europe-smartphone-tablet-wireless-earphone -makers-replaceable-batteries-proposal-2020-2 [https://perma.cc/8J96-79LN].

171. Anu Bradford, The Brussels Effect, 107 Nw. U. L. REV. 1, 29-30 (2012). 
1968. ${ }^{172}$ And beginning in 1975, federal standards have regulated vehicle fuel efficiency. ${ }^{173}$ Given the hundreds of billions of dollars U.S. consumers spend on electronics each year and the staggering environmental costs of disposable consumerism, such intervention may well be justified. ${ }^{174}$ Rather than regulatory oversight of the design process, the U.S. approach tends to focus on targeting consumer harm after the fact. But even from that perspective, regulators could be more proactive.

In 2019, the Federal Trade Commission held a workshop on third-party repair, recognizing that the issue falls within the FTC's broad jurisdiction. ${ }^{175}$ There are three distinct theories under which the FTC could pursue repair restrictions imposed by device makers: monopolization of the repair market, deceptive practices, and unfair practices. Each of these approaches deserves careful exploration, but my goal here is to briefly outline them.

Under the Supreme Court's decision in Eastman Kodak Co. v. Image Technical Services, Inc., limiting access to replacement parts may violate antitrust law. ${ }^{176}$ Kodak manufactured and sold photocopiers. After the company refused to sell replacement parts for those devices to owners and independent repair providers, the Court held that competition in the photocopier market did not absolve Kodak's monopolization of the post-sale parts and service markets. Subsequently, the Ninth Circuit rejected Kodak's assertion that exercise of its copyright and patent rights justified its anticompetitive conduct. ${ }^{177}$

Device makers who attempt to prevent repair could face antitrust liability under at least three theories. ${ }^{178}$ First, firms with market power that refuse to provide parts, tools, and information may violate the Sherman Act. ${ }^{179}$ Such claims are particularly

172. See 49 U.S.C. $\S \S 30101-12$.

173. Energy Policy and Conservation Act of 1975, Pub. L. No. 94-163, 89 Stat. 871.

174. Consumer Tech U.S. Sales to Reach Record \$422 Billion in 2020; Streaming Services Spending Soars, Says CTA, Associated Press (Jan. 6, 2020), https://apnews.com/Business\%20Wire/712622c00b204d8c96316abeca61d41e

[https://perma.cc/6ZVQ-URCG].

175. See Nixing the Fix: A Workshop on Repair Restrictions, Fed. TRAde Comm'N (July 16, 2019, 12:30 PM), https://www.ftc.gov/news-events/events-calendar/nixing-fix-workshoprepair-restrictions [https://perma.cc/R358-LZ5C].

176. 504 U.S. 451, 451 (1992).

177. Image Tech. Servs., Inc. v. Eastman Kodak Co., 125 F.3d 1195, 1212 (9th Cir. 1997) (affirming Sherman Act violations against manufacturer that refused to sell parts to independent service providers). But see Schor v. Abbott Labs., 457 F.3d 608, 613 (7th Cir. 2006) (describing the Image Technical decision as adopting "an undisciplined monopolyleveraging principle"); In re Indep. Serv. Orgs. Antitrust Litig., 203 F.3d 1322, 1326 (Fed. Cir. 2000) (declining to follow Image Technical in evaluating a "patentee's subjective motivation for refusing to sell or license its patented products").

178. See generally Daniel A. Hanley, Claire Kelloway \& Sandeep Vaheesan, Fixing America: Breaking Manufacturers' Aftermarket Monopoly and Restoring CONSUMERS' Right to REPAIR (2020) (surveying potential liability for repair restrictions under U.S. antitrust law).

179. See Aspen Skiing Co. v. Aspen Highlands Skiing Corp., 472 U.S. 585 (1985) (holding that ski resort's unilateral refusal to deal with a competitor could violate the Sherman Act). 
plausible if a device maker terminates an existing relationship that sacrifices shortterm profitability, as when Nikon cut off its authorized repair providers. ${ }^{180}$

Second, device makers may be liable for unlawfully tying products. Where a seller's market power over one product allows it to "force the buyer into the purchase of a tied product that the buyer either did not want at all, or might have preferred to purchase elsewhere on different terms," such tying arrangements are unlawful. ${ }^{181}$ So, when firms like John Deere make repair impossible without engaging the company's authorized providers, they may be unlawfully tying aftermarket services to equipment sales.

Finally, courts have recognized that the design of a product can itself be predatory. For example, among the bases for antitrust liability in its case against Microsoft, the government cited the company's exclusion of Internet Explorer from the Windows Add/Remove Programs utility and its decision to ignore users' default browser settings. ${ }^{182}$ Similar scrutiny has been applied to the design of medical devices, ${ }^{183}$ pharmaceuticals, ${ }^{184}$ and processors. ${ }^{185}$ But courts considering such claims are often quick to accept justifications for designs that indicate some motivation aside from restraining competition. More generally, given the long-running trend of anemic antitrust enforcement, repair providers alleging antitrust violations have not typically succeeded. ${ }^{186}$ At least one recent case, however, suggests these theories remain viable. ${ }^{187}$

Aside from antitrust violations, the FTC could consider the practice of selling consumers' devices subject to restrictive repair policies to be deceptive. A deception claim requires proof of: (1) "a representation, omission, or practice that is likely to mislead the consumer"; (2) the practice is examined from the perspective of a reasonable consumer; and (3) "the representation, omission, or practice must be 'material." "'188

Device makers rarely make explicit claims about the reparability of their products. Nor do they regularly assure consumers that they will be free to repair their devices

180. See Purdy, supra note 71. See also Verizon Commc'ns Inc. v. Law Offs. of Curtis V. Trinko, LLP, 540 U.S. 398 (2003).

181. Jefferson Parish Hosp. Dist. No. 2 v. Hyde, 466 U.S. 2, 12 (1984).

182. United States v. Microsoft Corp., 253 F.3d 34 (D.C. Cir. 2001).

183. C.R. Bard, Inc. v. M3 Sys., Inc., 157 F.3d 1340, 1369-72 (Fed. Cir. 1998) (arguing defendant's modification of its tissue sampling gun and needles prevented interoperability with plaintiff's products and was undertaken for predatory reasons).

184. New York ex rel. Schneiderman v. Actavis PLC, 787 F.3d 638, 659 (2d Cir. 2015) (affirming determination that the manufacturer's introduction of a once-daily Alzheimer's drug at the end of the patent term for a twice-daily version and subsequent withdrawal of that twicedaily version violated the Sherman Act).

185. Intel Corp., 61 F.T.C 247 (2010) (addressing Intel's alleged predatory redesigns and prohibiting it from making changes that degrade the performance of competitors products and do not provide an 'actual' benefit to its own products).

186. See Jonathan I. Gleklen, The ISO Litigation Legacy of Eastman Kodak Co. v. Image Technical Services: Twenty Years and Not Much to Show for It, 27 ANTITRUST 56, 62 (2012).

187. In Red Lion Medical Safety Inc. v. General Electric Company, a jury found that GE monopolized the market for repair of its anesthesia machines. No. 2:15-CV-308, 2016 WL 3770958 (E.D. Tex. Mar. 31, 2016).

188. Fed. Trade Comm'n, FTC Policy Statement on Deception, Opinion Letter (Oct. 14, 
using whatever parts or services they choose. In fact, the FTC has admonished some device makers for doing the opposite - unlawfully asserting that warranties will be voided for unauthorized repairs. ${ }^{189}$ Nonetheless, language used in the promotion and sale of devices may give rise to an actionable deception claim. ${ }^{190}$ More importantly, the omission of material information in advertising or other commercial communications can form the basis of deception. ${ }^{191}$ If consumers suffer from misimpressions or false understandings as the result of undisclosed information, they have been misled even if their misapprehension arises from consumer expectations rather than the seller's affirmative acts. ${ }^{192}$

The survey evidence indicates that consumers have strong expectations regarding their right to repair the devices they buy. More than $80 \%$ of respondents expressed their belief that they have the right to repair devices themselves or to rely on the repair shop of their choice. That figure is well above the significant minorityroughly 10 or $15 \%$ of consumers - typically necessary to establish deception. ${ }^{193}$ Admittedly, this conclusion is complicated by the range of tactics firms use to restrict repair and the variability of their success. The viability of unauthorized repair changes over time and between devices. But firms that succeed in limiting the availability of repair are acting in ways that are inconsistent with demonstrated consumer expectations.

Not only are repair restrictions misleading, they are material. The materiality requirement asks whether consumers would behave differently in the market if they were aware of the truth. In other words, if consumers knew that they would face hurdles to repairing their devices, would they refuse to purchase them? Would they purchase them only at a reduced price? ${ }^{194}$ Materiality can be presumed for claims relating to a product's cost and performance — characteristics that arguably relate to

1983).

189. See Proctor, supra note 162. The FTC sent letters to Sony, Microsoft, Nintendo, Hyundai, HTC, and ASUS giving the companies 30 days to alter their warranty policies, which prohibited unauthorized repair. Matthew Gault, FTC Gives Sony, Microsoft, and Nintendo 30 Days to Get Rid of Illegal Warranty-Void-if-Removed Stickers, VICE (May 1, 2018, 1:09 PM), https:/www.vice.com/en_us/article/xw7b3z/warranty-void-if-removed-stickers-sony -microsoft-nintendo-ftc-letters [https://perma.cc/5EB2-M7LM].

190. See Aaron Perzanowski \& Chris Jay Hoofnagle, What We Buy When We Buy Now, 165 U. PA. L. REV. 315, 343 (2017) (arguing that the Buy Now button for digital goods falsely communicates a set of rights inconsistent with license terms).

191. See, e.g., Market Dev. Corp., 95 F.T.C. 100, 212 (1980) (failing to disclose extra charges or conditions imposed on use of vacation certificates); Peacock Buick, Inc., 86 F.T.C. 1532, 1557-58 (1975) (failing to disclose handling and service fees), aff'd, 553 F.2d 97 (4th Cir. 1977).

192. Patricia P. Bailey \& Michael Pertschuk, The Law of Deception: The Past as Prologue, 33 Ам. U. L. REV. 849, 879-80 (1984).

193. See Novartis Consumer Health, Inc. v. Johnson \& Johnson-Merck Consumer Pharms. Co., 290 F.3d 578, 594 (3d Cir. 2002) ("[W]e believe that survey evidence demonstrating that $15 \%$ of the respondents were misled . . . is sufficient to establish . . . [a] claim for false or misleading advertising . . . .”); Firestone Tire \& Rubber Co. v. FTC, 481 F.2d 246, 249 (6th Cir. 1973) (affirming the FTC's finding of deception when an ad "misled $15 \%$ (or 10\%) of the buying public").

194. See supra Section III.B. 
repair. Otherwise, materiality hinges on direct evidence like surveys or consumer testimony. Again, the survey reported here strongly supports a finding of materiality. Across the device categories, roughly $70 \%$ of respondents indicated they would be less likely to buy devices - and willing to pay less for them-if they knew the manufacturer restricted repair.

Although the failure to disclose repair restrictions may constitute a deceptive practice, that conclusion will depend on circumstances, policies, and communications unique to specific device makers. Just as importantly, device makers may escape liability by providing some additional disclosure rather than altering the underlying restrictions.

As a result, the FTC's unfair practices authority may prove more powerful. For a practice to be unfair, the FTC needs proof of: (1) a substantial injury to consumers; (2) that is not outweighed by countervailing benefits to competition or consumers; and (3) that is not reasonably avoidable. ${ }^{195}$ Substantial consumer injuries can include monetary harm and the purchase of unwanted goods or services. So, policies or practices that force consumers to pay inflated prices for authorized repair would typically satisfy this requirement. In many cases, those price premiums may be hundreds or even thousands of dollars. But smaller harms may qualify when they are shared by large numbers of individuals.

Once a substantial injury is established, the question becomes whether it is outweighed by benefits to consumers or competition more broadly. Device makers would undoubtedly recite a litany of supposed benefits of monopolized repair markets - greater reliability, safety, and security, increased innovation, and lower upfront costs, among them. Many of these same arguments have been raised by lobbyists representing device makers in their conversations with state lawmakers. Proving them with actual evidence, however, is another matter. As the FDA has found, independent repair is effective and reliable. ${ }^{196}$ If that's true for life-saving medical technology, it's almost certainly true for our phones. As to the suggestion that innovation will decrease and prices will rise, the markups companies like Apple enjoy suggest that the market may benefit from reductions in both excess incentives and profits.

The final question is the extent to which consumers can avoid the injuries associated with repair restrictions. The temporal dimension of this question is significant. Once a consumer purchases an iPhone or John Deere tractor, for example, the harms of repair restrictions are unavoidable. And since those restrictions are typically not disclosed, consumers should not be expected to account for them in their purchasing decisions. Even before consumers make a purchase, these harms are often difficult to avoid. Again, because design features and company policies that frustrate repair are often hidden, it is difficult for consumers to comparison shop on the basis of reparability. Even if consumers could identify a comparable product unfettered by repair restrictions, markets for electronic devices are characterized by lock-in. ${ }^{197}$ Concerns about interoperability often compel consumers to stay within

195. See Fed. Trade Comm'n, FTC Policy Statement on Unfairness, Opinion Letter (Dec. 17, 1980).

196. See U.S. Food \& Drug AdMin., supra note 145.

197. See Hoofnagle, Kesari \& Perzanowski, supra note 54, at 829. 
one manufacturer's product ecosystem, reducing the degree to which they can avoid the harms of exclusive repair policies. And within highly concentrated consumer products markets, choices are often limited, and repair restrictions may be commonplace across entire product categories, further bolstering the case for unfairness.

\section{CONCLUSION}

The data presented here demonstrate that consumers expect and value the right to repair the products they buy. But the practices and policies adopted by device makers - from product design and pricing to contract terms and assertions of intellectual property rights - interfere with those expectations. The right to repair bills pending in states around the country would help ensure the availability of parts, tools, and information crucial to a functioning independent repair market. But establishing a robust right to repair will require lawmakers, courts, and regulators to confront the full range of repair restrictions and to adopt more aggressive, multifaceted policy interventions to fully protect the interests of consumers. 